\title{
Structural expression of a fading rift front: a case study from the Oligo-Miocene Irbid rift of northwest Arabia
}

\author{
Reli Wald ${ }^{1}$, Amit Segev ${ }^{2}$, Zvi Ben-Avraham ${ }^{3}$, and Uri Schattner ${ }^{1}$ \\ ${ }^{1}$ The Dr. Moses Strauss Department of Marine Geosciences, Leon H. Charney School of Marine Sciences, Haifa University, \\ Mt. Carmel, Haifa 31905, Israel \\ ${ }^{2}$ Geological Survey of Israel, 30 Malkhe Israel, Jerusalem 95501, Israel \\ ${ }^{3}$ Department of Geophysics and Planetary Sciences, Tel Aviv University, Tel Aviv 69978, Israel
}

Correspondence: Reli Wald (rwald@campus.haifa.ac.il)

Received: 8 September 2018 - Discussion started: 8 October 2018

Revised: 14 December 2018 - Accepted: 23 December 2018 - Published: 31 January 2019

\begin{abstract}
Not all continental rifts mature to form a young ocean. The mechanism and duration of their cessation depend on the crustal structure, modifications in plate kinematics, lithospheric thermal response, or the intensity of subcrustal flow (e.g., plume activity). The cessation is recorded in the structure and stratigraphy of the basins that develop during the rifting process. This architecture is lost due to younger tectonic inversion, severe erosion, or even burial into greater depths that forces their detection by lowresolution geophysical imaging. The current study focuses on a uniquely preserved Oligo-Miocene rift that was subsequently taken over by a crossing transform fault system and, mostly due to that, died out. We integrate all geological, geophysical, and previous study results from across the southern Galilee to unravel the structural development of the Irbid failing rift in northwest Arabia. Despite tectonic, magmatic, and geomorphologic activity postdating the rifting, its subsurface structure northwest of the Dead Sea fault is preserved at depths of up to $1 \mathrm{~km}$. Our results show that a series of basins subsided at the rift front, i.e., rift termination, across the southern Galilee. We constrain the timing and extent of their subsidence into two main stages based on facies analysis and chronology of magmatism. Between 20 and $9 \mathrm{Ma}$ grabens and half-grabens subsided within a larger releasing jog, following a NW direction of a deeper presumed principal displacement zone. The basins continued to subside until a transition from the transtensional Red Sea to the transpressional Dead Sea stress regime occurred. With the transition, the basins ceased to subside as a rift, while the Dead Sea fault split the jog structure. Between 9 and $5 \mathrm{Ma}$ basin subsidence
\end{abstract}

accentuated and an uplift of their margins accompanied their overall elongation to the NNE. Our study provides for the first time a structural as well as tectonic context for the southern Galilee basins. Based on this case study we suggest that the rift did not fail but rather faded and was taken over by a more dominant stress regime. Otherwise, these basins of a failing rift could have simply died out peacefully.

\section{Introduction}

Failed continental rifts mark regions where crustal extension began in the past but did not mature into continental breakup. Their extension first forms an elongated valley that hosts a series of subsiding basins. Seismicity and volcanism accompany the subsidence, as observed along the Rhine Graben, the East African Rift, the Baikal Rift, and the Shanxi Rift of China (Ziegler and Cloetingh, 2004). However, some rifts fail to mature beyond this stage. Their seismicity, volcanism, and overall extension gradually cease. They become aulacogens, also called failed rifts, paleo-rifts, and aborted rifts (Hoffman et al., 1974; Şengör, 1995; Brueseke et al., 2016).

Rifting cessation may result from modifications in plate kinematics or in lithospheric thermal re-equilibration (e.g., along the Ordovician-Silurian Transbrasiliano Lineament; Oliveira and Mohriak, 2003). It could also reflect a decay in plume intensity (e.g., Delhi basin; Sharma, 2009) or variations in rheological properties (Lyakhovsky et al., 2012). In this case, the extensional strain is accommodated by local- 
ized deformations over a wider region than the original rift axis (Van Wijk and Blackman, 2005; Segev et al., 2014).

The mechanism and duration of the cessation vary from one case to another. A rapid stop might be a result of extensional stress decay, acquaintance with a more rigid crust, or a newly established stress regime different enough to mute the rifting process. Fading, i.e., gradual decrease in the dominant rifting stress, leads to attenuation and eventually rift abortion. In the Potiguar rift (Brazil) case, Precambrian basement faulting patterns dictated the Neocomian-Barremian syn-rift graben formation style. Magnetic, gravity, and resistivity data delineated intraplate transform boundaries, which generated fault-controlled depressions. Both the NE-trending (parallel to rift axis) oblique-slip faults and the $\mathrm{N}-\mathrm{S}$-trending en-echelon normal faults die out in the post-rift sedimentary units (de Castro and Bezerra, 2015). In southeastern Australia, a transform fracture zone cuts across preexisting basement structures. Folds and foliations of previous structural stages present unfavorable orientations for reactivation under the present stress field (Lesti et al., 2008).

Preservation of failed rift structures in the geological record depends on the intensity and efficiency of later tectonic and erosion processes. In some cases, the internal architecture and thus the imaging resolution of the basins comprising a failed rift may be lost due to tectonic inversion, severe erosion, or even burial into greater depths (Beauchamp et al., 1996, 1999; Guiraud and Bosworth, 1997; Dézes et al., 2004). The reconstruction of the architecture depends on the geophysical imaging resolution (d'Acremont et al., 2005; Enachescu, 2006; de Vicente and Muñoz-Martin, 2013; Melo et al., 2016). The current study focuses on the structural development of a rift front, its failure, and later preservation. We concentrate on the Irbid rift (also referred to as the Azraq-Sirhan or Qishon-Sirhan rift) that developed across the Arabian Plate and into the Sinai subplate during the Oligocene-Miocene (Schattner et al., 2006a; Segev et al., 2014; Fig. 1). Despite tectonic, magmatic, and geomorphologic activity postdating the rifting, the original subsurface structure of the failed rift is preserved at depths of up to $1 \mathrm{~km}$.

\section{Regional geological setting}

The Precambrian basement underlying the Galilee assembled during the pan-African orogeny until $\sim 620$ Ma (Bentor, 1985; Stern, 1994; Stein and Goldstein, 1996; Stern and Johnson, 2010). Subsequent truncation eroded a 6-10 km thick section from the Galilee area (Garfunkel, 2002). The Paleozoic opening of the Palmyride rift (overlapping the current location of the Palmyride Belt; Fig. 1) crossed the Galilee in a NNE orientation (Walley, 1998; Segev and Eshet, 2003). Opening of the Levant basin (Garfunkel and Derin, 1984; Robertson, 1998; Garfunkel, 1998, 2004; Gardosh et al., 2008) during the Early Cretaceous (Segev et al., 2018) redefined the formerly inland Galilee region as a new conti- nental margin. The passive margin accumulated marine sediments until the Late Cretaceous.

Progressive closure of the Neotethys Ocean at the northern Arabian Plate (Stampfli and Hochard, 2009; Frizon de Lamotte et al., 2011) induced compressional stresses across the Levant margin. The stresses inverted the extensional grabens formed 100-200 Myr earlier and folded the Levant margin (Sagy et al., 2017). A $\sim 50 \mathrm{~km}$ wide $\mathrm{S}$-shaped fold belt developed from northern Sinai, through Israel, and along the Palmyride region (the "Syrian Arc"; Krenkel, 1924; Hensen, 1951; Guiraud and Bosworth, 1997; Walley, 1998; Hardy et al., 2010). Compressional stresses kept the margin at shallow depths, while the syn-tectonic chalks of the SantonianPaleocene Mount Scopus Gr. covered the Late Cretaceous relief. During the Paleogene-Eocene tectonic and thermal quiescence led to gravitational vertical subsidence of NW Arabia. The resulting transgression submerged the entire Galilee under more than $1000 \mathrm{~m}$ of ocean water. Lower to middle Eocene sediments comprise mainly chalks and limy chalks with sporadic chert nodules and chert layers (Sneh et al., 2000a; Segev et al., 2011).

Mantle upwelling of the Afar plume began at the late Eocene, uplifting the overlying crust (Hofmann and Curtillot, 1997; Pik et al., 2003; Avni et al., 2012, and references therein). Part of the mantle plume volume propagated northwards away from the plume head during the Oligocene-early Miocene $(\sim 25-17 \mathrm{Ma})$. Its imprint on surface topography was recorded as a gradual and continuous uplift migration across northeastern Africa, gradually exposing the region above sea level. The exposure led to a regional truncation that leveled the area into a low-relief peneplain over merely $7 \mathrm{Myr}$ (e.g., Egypt, Jordan, southern and central Israel; Picard, 1943, 1951; Quennell, 1958; Garfunkel and Horowitz, 1966; Garfunkel, 1970; Horowitz, 1979, 1992, 2001; Ben David and Mazor, 1988; Zilberman, 1989, 1992; Avni, 1991, 1993 , 1998; Ben David, 1993; Bar et al., 2013, 2016; Avni et al., 2012). In the Galilee, the regional truncation surface (RTS) serves as a marker, dividing between marine carbonates below and lacustrine, fluvial, and volcanic rocks above (Picard, 1943; Wald et al., 2014, 2019; Wald, 2016). Meanwhile, Eocene chalks and Paleocene-early Miocene greenish-gray shales and marls accumulated on the Levant margin (Fig. 2; Gvirtzman et al., 2011; Steinberg et al., 2011).

The Afar uplift was accompanied by a regional crustal extension and the formation of two NE-SW-trending coeval rifts (Schattner et al., 2006a). The NW-trending Red SeaSuez rift divided Arabia from Africa (Steckler and ten Brink, 1986; Bosworth et al., 2005), while the NW-trending Irbid rift developed across the Arabian Plate. The northwestern front of the Irbid rift crosses the southern Galilee (Fig. 1; Shaliv, 1991; Schattner et al., 2006a). The Irbid rift divides two crustal terranes that differ in thickness and seismicity (Ginzburg et al., 1994; Hofstetter et al., 1996; Ben-Avraham et al., 2002; Segev et al., 2006) and possibly form two different subplates (Palano et al., 2013; Schattner and Lazar, 

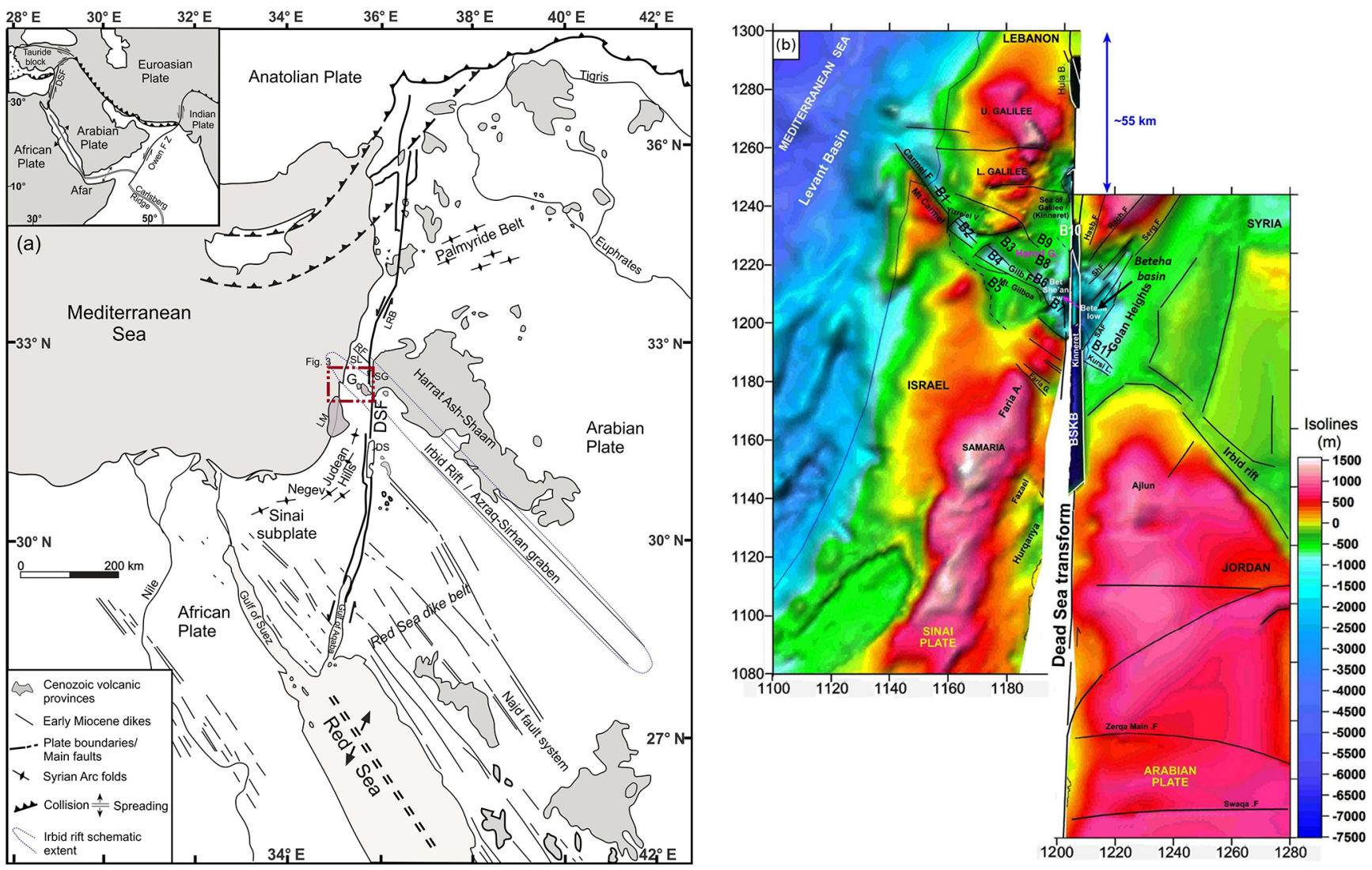

Figure 1. (a) Major tectonic, magmatic, and sedimentary elements along the eastern Mediterranean basin and surrounding plates (after Garfunkel, 1989; Ilani et al., 2001; Schattner et al., 2006a, b; Segev et al., 2014, 2017). Schematic extent of the Irbid rift is outlined in dashed blue lines. Inset - main tectonic elements in the vicinity of the Arabian Plate - the Dead Sea fault (DSF), Afar dome, and the Owen fracture zone (FZ). The Cretaceous Syrian Arc fold belt extends from Egypt to Syria across the Galilee. LM - Levant margin; G - Galilee; RF Roum fault; SL - southern Lebanon; SG - Sea of Galilee (Fig. 3 for zoom-in); DS - Dead Sea; LRB - Lebanese restraining bend. Bordeaux outline - study area, presented in Fig. 3. (b) Reconstructing the pre-DSF plate configuration using the structural map of the top Judea Group interface (modified from Segev et al., 2014). The Beteha basin on the Arabian Plate is attached to the Bet She' an basin on the Sinai subplate, which showed a $\sim 55 \mathrm{~km}$ motion along the DST. Basins referred to herein are marked by the B series (B1 to B11). Abbreviations: F., fault; V., valley; B., basin; L., low; Mt., Mount; Hasb., Hasbaya; Rach., Rachaya; Serg., Serghaya; SAF, Sheikh Ali fault; BSKB, Bet She'an Kinarot basin; DST, Dead Sea transform.

2013). A series of basins subsided along the NW-propagating Irbid rift. They developed across the present-day Galilee up to the Levant continental margin (Lyakhovsky et al., 2012; Segev et al., 2014). However, unlike the Red Sea, spreading across the Irbid rift failed to mature into a young ocean (Shaliv, 1991; Schattner et al., 2006a). The Galilee basins subsided during the late Oligocene-Miocene terminal stages of the Irbid rift. They maintained their low topographic relief despite intense tectonic activity along the nearby Dead Sea fault plate boundary (Shaliv, 1991; Matmon et al., 2003).

Lateral motion along the $\mathrm{N}-\mathrm{S}$-trending Dead Sea fault (DSF) plate boundary initiated between $18 \mathrm{Ma}$ (Freund, 1970; Garfunkel, 1981, 1998; Joffe and Garfunkel, 1987) and $14 \mathrm{Ma}$ (Bayer et al., 1988; Bosworth et al., 2005). In a recent study, Nuriel et al. (2017) dated the onset of motion along the DSF. Their calcite age-strain analyses yielded ages of 20.8-18.5 Ma for the southern DSF and 17.1-12.7 Ma for the
DSF in northern Israel (next to our study area). The motion decapitated the Irbid rift and isolated the Galilee basins on the newly formed Sinai subplate (Schattner et al., 2006a). Transtension along the DSF resulted in further subsidence of basins along it during the late Miocene to early Pliocene (Garfunkel, 1981; Joffe and Garfunkel, 1987; Smit et al., 2010). Around $5 \mathrm{Ma}$ the lateral displacement along the DSF reached $\sim 40 \mathrm{~km}$, while extension across the valley was $\sim$ $4 \mathrm{~km}$ (Joffe and Garfunkel, 1987). However, since $5 \mathrm{Ma}$ subsidence of the basins along the DSF accentuated (e.g., Gulf of Aqaba, Dead Sea, and Hula basins; Figs. 1 and 3; Garfunkel and Ben-Avraham, 2001). This trend was also recorded in the basins situated at the junction between the DSF and Irbid rift trends (Figs. 1 and 3): Bet She'an (B7), Kinarot (B10), and Sea of Galilee basins (Hurwitz et al., 2002; Segev et al., 2014; B7, B10 in Fig. 3). Further north, increased transpressional motion along the DSF (Freund, 1970; Schattner 


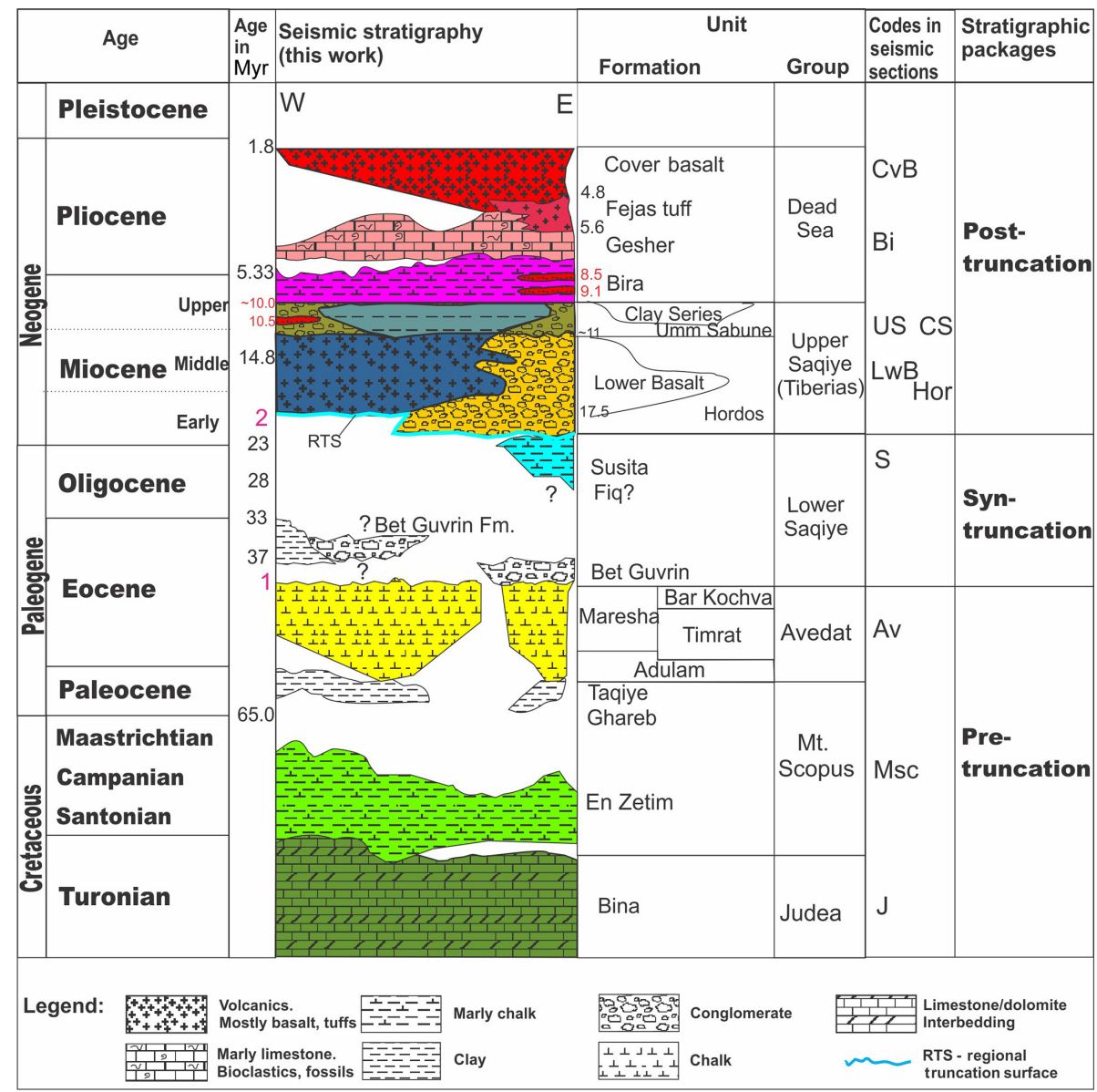

Figure 2. Stratigraphic correlation across the Galilee. Pink numbers $(1,2)$ represent unconformity surfaces. Radiometric ages (in million years, i.e., Myr) from Shaliv (1991), Heimann et al. (1996), and Segev (2000). Dating of Fejas tuff, Gesher, and Cover Basalt formations (shown in red) from Rozenbaum et al. (2016). Base of Cover Basalt age is from site 3 of Dembo et al. (2015). CvB - Cover Basalt Formation.; Bi - Bira Formation; US - Umm Sabune Formation; CS - Clay Series; S - Susita Formation; Av - Avedat Group; MSc - Mt. Scopus Group; J - Judea Group.

and Weinberger, 2008; Weinberger et al., 2010) uplifted the Lebanese restraining bend (Fig. 1; e.g., Walley, 1998; Gomez et al., 2006, 2007). Contraction of the bend induced a N-S extension of the Galilee basins. As a result, the formerly Irbid rift basins remained low in both structure and topography (Schattner et al., 2006a, b).

\section{Morpho-tectonics of the southern Galilee basins}

The southern Galilee Neogene basins extend across $\sim 50 \mathrm{~km}$ between the DSF and the Levant continental margin (Fig. 3). The Carmel-Gilboa (C, GL in Fig. 3b) and Zurim fault ( $\mathrm{Z}$ in Fig. 3b) systems in the south and north (respectively) bound the southern Galilee basins (Schattner et al., 2006a, b). Their $\mathrm{N}-\mathrm{S}$ extent narrows westwards from $\sim 35$ to $\sim 10 \mathrm{~km}$ in a low relief that exhibits sporadic highs dividing local valleys. The surface of the westernmost basin, Yizre'el (B2), is at 30-70 m a.s.l. To the east Kesulot (B3) and Taanach (B5) basins are at $60-100 \mathrm{~m}$, Harod basin (B6) is between 30 and $-210 \mathrm{~m}$, and Bet She'an (B7) is at $-250 \mathrm{~m}$. The low relief of the southern Galilee basins (i.e., valleys and intervening small hills) divides two segments of the Mesozoic Syrian Arc fold belt (Krenkel, 1924; Fig. 3b). The remnant Mesozoic Syrian Arc fold belt, which currently builds the Israeli hilly backbone, has risen by $\sim 500 \mathrm{~m}$ since the Pliocene (Fig. $3 \mathrm{~b}-$ GL, C, UEF, N, SF). Lower Cretaceous (Kurnub Group) and Jurassic (Arad Group) exposures appear in limited areas. The upper Cretaceous Judea and Mount Scopus groups are exposed mainly along the fold belt truncated crests, for example along the Gilboa, Carmel, and Nazareth ridges. The fold belt synclines are also uplifted to $\sim 250 \mathrm{~m}$, exposing the Eocene Avedat Group (across Tiv'on and Menashe hills; Fig. 3).

Sedimentary infill of the southern Galilee basins comprises intercalations of siliciclastic, volcanic, and carbonate lithologies of the Dead Sea and the Upper Saqiye (previously Tiberias) groups (Fig. 2). They accumulated mainly un- 

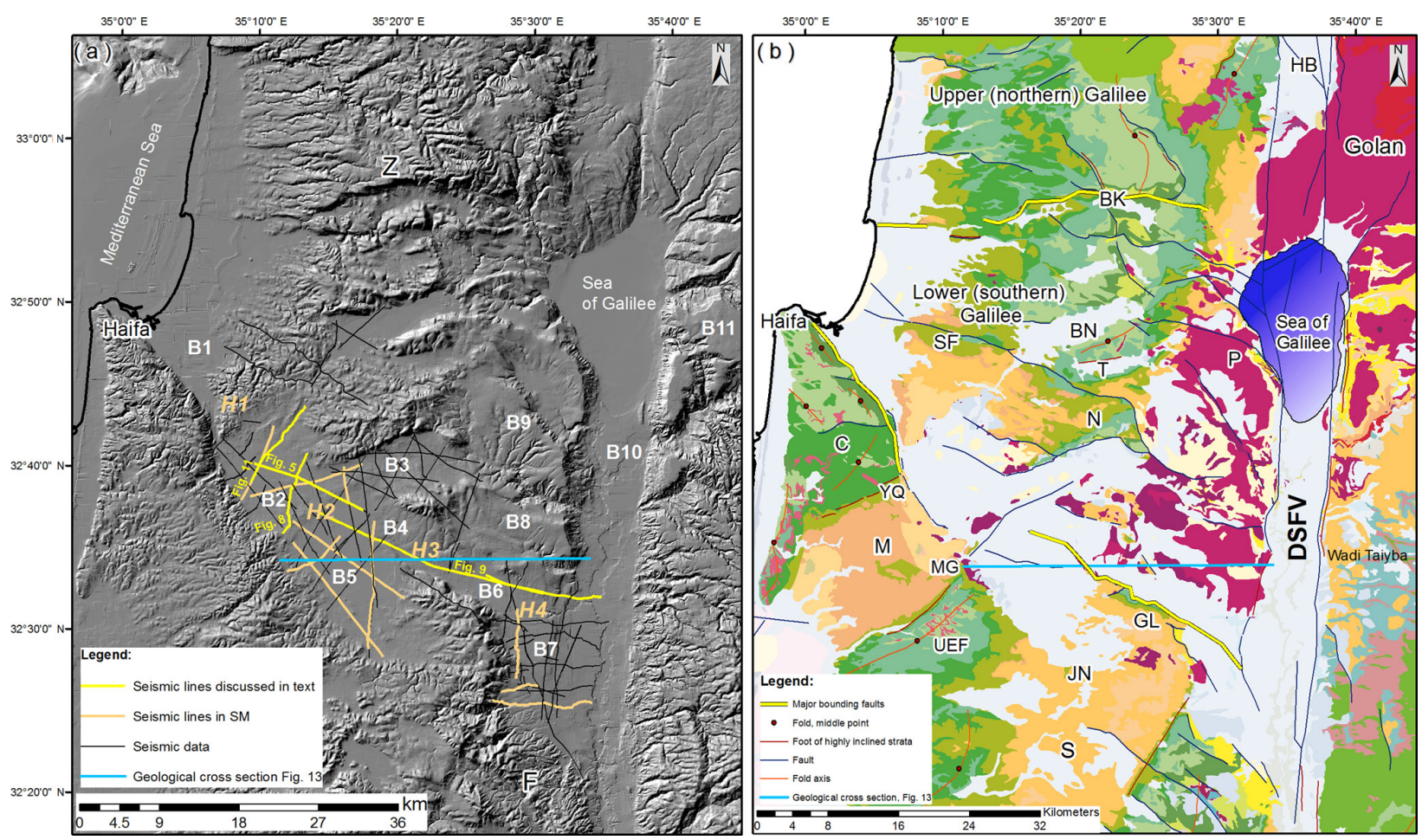

Figure 3. Location map of the study area, Sinai subplate. (a) Location of the multichannel seismic reflection profiles used in this study on a shaded relief digital elevation model (DEM; Sneh et al., 2000b). Local names of the basins and the structural highs are abbreviated to simplify the description as follows: B1 - Zevulun basin, B2 - Yizre'el basin, B3 - Kesulot basin, B4 - Afula basin, B5 - Taanach basin, B6 - Harod basin, B7 - Bet She' an basin, B8 - Moledet basin, B9 - Sirin basin, B10 - Kinarot basin, B11 - southern Golan basin. H1 - Tiv'on hills, H2 - Hayogev-Mizra horst, H3 - Navot high, H4 - Sede Nahum high. (b) A 1 : 200000 geologic map (Sneh et al., 1998). Note major faulted boundaries: the Carmel-Gilboa (C-GL) southern fault boundary and the Zurim escarpment northern fault boundary. For color code see Fig. 2, with two exceptions - Lower Basalt Fm. (purple in map) and the Neogene formations: Hordos, Clay Series, Bira, and Gesher all of which appear in cream. Abbreviations: F - Faria anticline, Z - Zurim escarpment, dividing between upper and lower Galilee, BN - Bet Netofa, BK - Bet Hakerem, P - Poriyya, T - Tur' an, SF - Shefar' am, TVN - Tiv'on, N - Nazareth, C - Mt. Carmel, M - Menashe syncline, S - Shekhem syncline, YQ - Yoqne'am, MG - Megiddo, UEF - Umm El Fahm anticline, JN - Jenin, GL - Mt. Gilboa, DSFV - Dead Sea fault valley, $\mathrm{HB}$ - Hula basin.

der continental (lacustrine-fluvial) conditions with phases of shallow marine intercalations. Since the early Miocene and until the present, the relatively high rims of the basins have contributed clastics that accumulated in the basins (Shaliv, 1991; Sandler et al., 2004; Rozenbaum et al., 2016). This mixture resulted in a discontinuous and irregular distribution of sedimentary units and facies across the southern Galilee basins. Some of the units wedge laterally (e.g., Umm Sabune Conglomerate Fm., Bira Fm. in Fig. 2), while others appear only locally.

A series of studies conducted over the last half-century provide invaluable insights into the stratigraphy, hydrology, geophysics, and outcrop mapping of the study area and its surroundings. They include master's and $\mathrm{PhD}$ theses as well as reports and peer-reviewed papers (e.g., Schulman, 1962; Sass, 1966; Yair, 1968; Weiler, 1968; Dicker, 1969; Klang and Sherman, 1972; Dekel, 1988; Shaliv, 1991; Hatzor, 1988; Gev, 1989; Sneh et al., 1998; Gardosh and Bruner, 1998; Bartov et al., 2002; Rotstein et al., 2004; Sagy and Gvirtzman,
2009; Segev et al., 2006; Abelson et al., 2009; Zilberman et al., 2009). Some of the studies focused on volcanism, paleodrainage, and paleohydrology of the Yizre'el basin (Yair, 1968; Schulman, 1962; Wishkin, 1973; Shaliv, 1991; Gev, 1989; Baer et al., 2006). Geophysical studies showed the architecture of basins along the southern Galilee: Bet She'an basin (Meiler et al., 2008; Gardosh and Bruner, 1998; B7 in Fig. 3); Zevulun basin (Sagy and Gvirtzman, 2009; B1 in Fig. 3); and Taanach and Yizre'el basins (Politi, 1983; Rotstein et al., 2004; B5 and B2 in Fig. 3). These studies focused on localized structures across the southern Galilee basins and left the larger regional context unresolved. The current study integrates all the previous results with unpublished data to address fundamental questions regarding the origin and development of the lower Galilee. It surveys the geometry of the basins to clarify regional structural relationships: is it a single continental basin that accumulated sediments from its surrounding rims (Picard, 1943; Schulman, 1962; Shaliv, 1991)? Alternatively, maybe it is a full graben 
bounded by longitudinal faults, Zurim and Carmel-Gilboa from the north and south, respectively (as suggested by Kafri and Ecker, 1964; Mero, 1983), or possibly a couple of halfgrabens bounded by these faults (as proposed by May, 1987; Matmon et al., 2003)? What is the structural and tectonic association between the southern Galilee basin development and the nearby DSF and Levant continental margin? More specifically, what is the relationship between the southern Galilee basins and the Irbid rift? In what manner does the structural development of the southern Galilee basins relate to the regional volcanic events?

\section{Dataset and methodology}

Geological reconstruction of the structure and development of the southern Galilee basins relies on an integrated interpretation of all available geophysical and geological datasets from the study area. The new database was constructed on the Kingdom Suite (IHS) platform. It includes 70 multichannel seismic reflection profiles, 506 boreholes, outcrop data, and previous seismic interpretations. The seismic reflection data were acquired from the 1970s through the 2000s. The profiles cover a total length of $800 \mathrm{~km}$. The average depth imaging is $500-1000 \mathrm{~m}$ below the seismic datum (sea level). The borehole depth ranges between 35 and $2390 \mathrm{~m}$ below the surface. Seismic resolution enables the interpretation of geological units starting from the upper Cretaceous (Fig. 2).

Stratigraphic, hydrological, geophysical, and outcrop datasets collected in the past across the study area are integrated here into a single database in a WGS 1984UTM $36 \mathrm{~N}$ datum projection, bridging over gaps in vertical and horizontal resolution, reflector amplitudes, processing methods, and data. These sources include Schulman (1962), Sass (1966), Aizenberg (1967), Yair (1968), Weiler (1968), Dicker (1964, 1969), Klang and Sherman (1972), Dekel (1988), Shaliv (1991), Hatzor (1988), Gev (1989), Sneh et al. (1998), Gardosh and Bruner (1998), Bartov et al. (2002), Rotstein et al. (2004), Sagy and Gvirtzman (2009), Segev et al. (2006), Abelson et al. (2009), and Zilberman et al. (2009). Data were further used for constructing structural maps of key surfaces. The surfaces and faults were exported from the Kingdom Suite to Petrel (Schlumberger) to build a structural model. Results of previous geological mapping were used to extend the structural model from sea level datum (elevation of $0 \mathrm{~m}$ ) up to the presentday topography (30-550 $\mathrm{m}$ a.s.1.). Two velocity surveys were done in the area (Sarid 1 and Revaya 7 wells; SM3, 7, 9). The synthetic seismogram of Revaya 7 well (Frieslander, 1997; Meiler et al., 2008) enabled a reliable stratigraphic correlation with the seismic data. In addition, using a $2000 \mathrm{~m} \mathrm{~s}^{-1}$ velocity for the shallow, near-surface beds (weathered beds) enabled correlation between depth and time domains. Completion of the structural model relied upon digitization of truncation surfaces from previous studies in ArcMap (ESRI)
(Weiler, 1968; Dicker, 1969; Dekel, 1988; Shaliv, 1991, 2003; Sneh, 2008). Outcropping truncated surfaces are considered as layers within a specific unit rather than its top (due to erosion). Control points were added from boreholes. Integration of all datasets yielded a coherent database and a three-dimensional geological grid model of the Galilee subsurface extending from a depth of $2500 \mathrm{~m}$ to the present-day surface topography.

\section{Results}

This section describes the sedimentary fill of the basins in chronological order. It is followed by a description of the structural elements. Local names of the basins and the structural highs (i.e., uplifted blocks) are abbreviated to simplify the description (Fig. 3). All geographical locations mentioned in text appear in the Google Earth ${ }^{\mathrm{TM}}$ Supplement, herein referred to as GE. The sedimentary fill is bounded between two temporal and structural markers. The basin floor is marked by the Oligo-Miocene regional truncation surface (RTS; 23-17 Ma; Figs. 2 and 4), a peneplain predating the subsidence of the basins. The RTS truncates the folded and displaced structures of the Judea, Mt. Scopus, and Avedat groups (Fig. 2). The latter is thinning towards $\mathrm{H} 2$ and pinches out approximately $400 \mathrm{~m}$ west of it (Fig. 5). An important surface culminating the Neogene sedimentary fill is the top of the Bira Fm., depicting a very mild relief. The Cover Basalt Fm. locally covers it and provides a temporal marker. Analysis of the entire database indicates that the type section is located along the axis of the southern Galilee basins (B2, B4, B6, and B7). Basin depocenters align along a northwest axis (Figs. 1b and 7). Further details from B3, B5, and B8-B9 basins complete the section. Additional information from B1, B10, and B11 is provided in the discussion (location: Fig. 3).

\subsection{Basin fill}

The oldest formations deposited above the RTS are the contemporaneous Lower Basalt and Hordos fms. (Fig. 2). Today, these formations appear in the subsurface and also outcrop across marginal areas and local highs (Fig. 6). The Hordos Fm. predates the Lower Basalt Fm., yet their seismic appearance is similar. They resemble each other in reflection frequency, amplitude, and continuity. Some differences between these formations appear in parts of B7. Seismic and borehole data (Figs. 9, S5, S8, S14) show that the Hordos Fm. covers the floor of the B6-7 and 10 basins and thickens southwards along the DSF. Further up the section, it inter-fingers with the Lower Basalt Fm. that thins southwards along the DSF. The Lower Basalt Fm. directly overlies the basin floor in B2-5, excluding local highs (Figs. 5 and 7). The concordant seismic appearance of the formation hints to the consecutive succession of basalt flows and the hiatuses between them (Figs. 5, 7, and 8). The lateral continuation of reflec- 

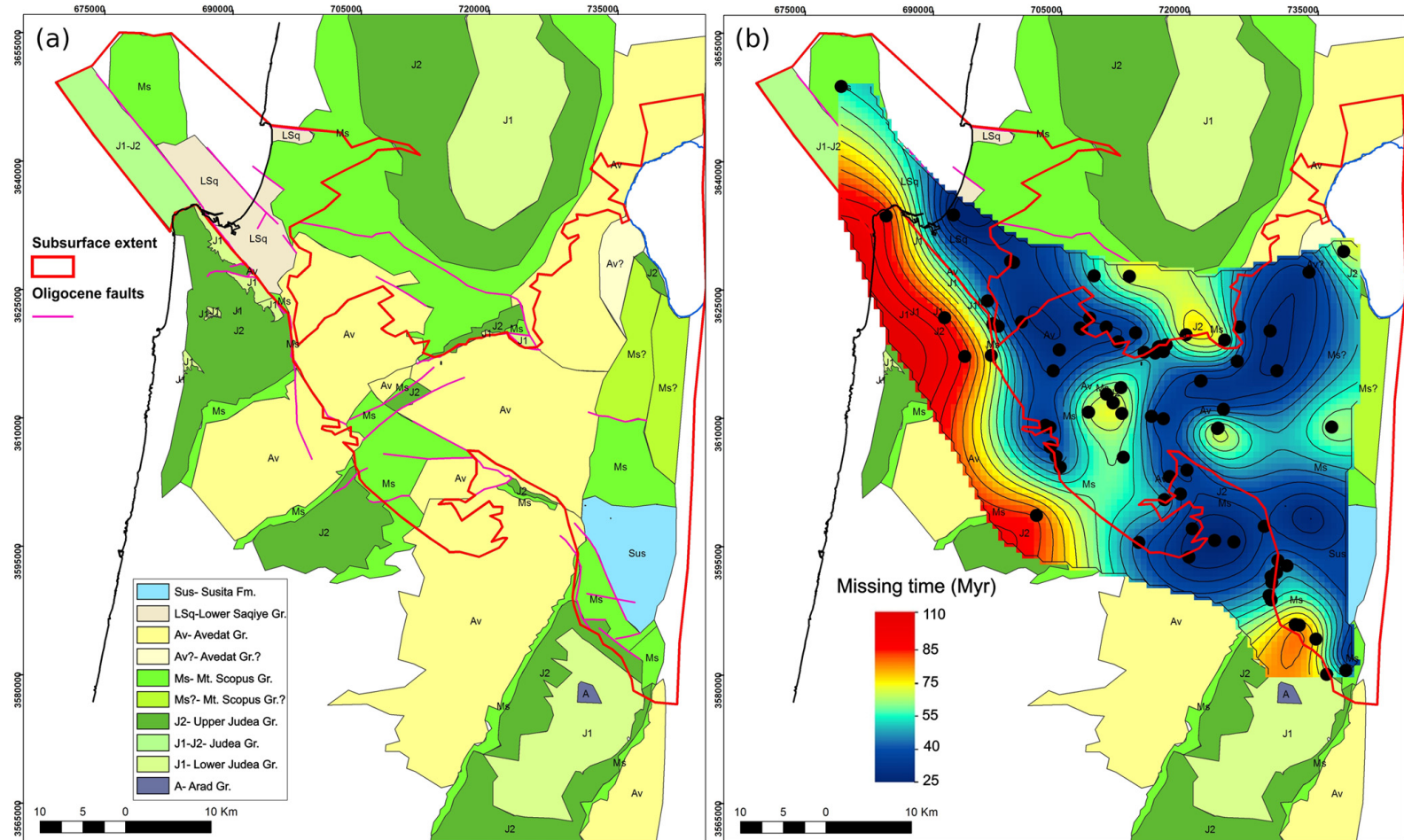

Figure 4. (a) Subcrop map of the Oligocene regional truncation surface (RTS) in the UTM GWS1984 Zone 36N projection. The map shows the youngest units truncated by the RTS based on the integrated interpretation of geological and geophysical data from the surface and subsurface. Colors correspond to the seismic profiles. Red polygon marks the extent of data gathered in the current study. (b) Spatial variation in truncation across the Galilee is a product of kriging interpolation, further represented by contours of equal time gap in million years. Black dots mark locations where the youngest unit below RTS and older unit from above are available for quantifying the time gap (the time gap is discussed in Wald et al., 2019). Some of the data points are today exposed above the datum of the map. Note that some of the points may include pre-Oligocene truncations.

tors degrades towards fault and fold zones, representing displacement events postdating the accumulation of the Lower Basalt Fm. (Figs. 9-11; Figs. S1-S4, S8, S10 in the Supplement). The Lower Basalt Fm. is missing from B1, where the oldest basin fill unit comprises marls associated with the Bet Guvrin Fm. (Lower Saqiye Group; Figs. 3 and 4).

Numerous seismic, borehole, and outcrop datasets indicate that the Lower Basalt Fm. generally thickens towards the center of each of the basins (Fig. S6). The thickening is also indicated by the arrangement of main faults, dikes, and volcanic feeders (Figs. 5, 10, 11, and S1-S5). In B3-7 and $\mathrm{H} 2$ the thickness exceeds $100 \mathrm{~m}$. In B2, the Lower Basalt Fm. fills a Cretaceous syncline while onlapping its flanks. It thickens from a few meters over $\mathrm{H} 1$ to a constant $\sim 125 \mathrm{~m}$ at the center of B2. The thickness of the Lower Basalt Fm. reaches $400-600 \mathrm{~m}$ adjacent to $\mathrm{H} 2$ (Fig. 10). At the western part of B4, a borehole crossed $630 \mathrm{~m}$ of the Lower Basalt Fm. (Table 1). However, this is a minimal value since the base of the formation has not been reached. B3 is divided into two sub-basins by H2. The eastern part of B3 accumulated 50$100 \mathrm{~m}$ of Lower Basalt Fm., while the western part accumulated at least $350 \mathrm{~m}$ (base of the formation was not reached).
In the eastern border of B4 and B5, the Lower Basalt Fm. reflectors onlap an elevated Eocene block $(\mathrm{H} 3)$ at $\sim 10^{\circ}$. The Lower Basalt Fm. thickness does not exceed $200 \mathrm{~m}$ in B5. Its reflectors appear parallel-subparallel to the basin floor (RTS, Figs. S3 and S16). Further east, near the B6-7 Lower Basalt Fm., thickness varies considerably between 395 and $750 \mathrm{~m}$ (Table 1). In B10 the Lower Basalt Fm. reaches $3500 \mathrm{~m}$ (Table 1). The southern subsurface limit of the Lower Basalt Fm. is the Nahal Bezek fault, whereas a localized outcrop several tens of meters thick appears further south in Marma Fayad (location: Fig. 6, Google Earth Archive-GE; Figs. 6, 7, and 10a).

The top of the Lower Basalt Fm. is an erosional unconformity that accentuates eastwards, according to the age of the units overlying it (Figs. 2, 3, 6, and S5). In the west, the Umm Sabune conglomerate and Clay Series fms. overlay the Lower Basalt in B2-5 basins (Figs. 5, 8, and 11). The Bira Fm. covers this unconformity over the $\mathrm{H} 2$ and $\mathrm{H} 3$ structural highs and across B6 (Fig. 9). In the eastern Galilee (B8-9) and B7, the top Lower Basalt unconformity is either directly overlain by the Cover Basalt Fm. at elevated terrains (e.g., Yisachar-Gazit and Hashita-Geva blocks of B8; loca- 
tion: Fig. 10a) or covered by the Bira Fm. (Figs. 3, 10, and S8).

The clastic formations of the Dead Sea Gr. overlie the truncated top of the Lower Basalt Fm. (Figs. 8, 9, 11, S1-S6, S8, $\mathrm{S} 10$, and S14). Data indicate that the group accumulated during the upper Miocene-Pliocene in a lacustrine-fluvial environment. Appearances of lumachelle ostracods at the Bira Fm. indicate an episodic connection to the marine environment. Interchanging paleosol horizons and volcanic remains crossed in boreholes point to exposed continental environments. The Umm Sabune Conglomerate Fm. overlies the Lower Basalt Fm. at H1, the margin of B2 (Kishon 1 borehole; Fig. 8, GE), and in the eastern Galilee. The conglomerates appear near the margins of the basins and volcanic centers. They are bounded by the intersection between Gevat and Nazareth faults (Fig. S7). The Umm Sabune Conglomerate Fm. contains basaltic pebbles derived from the Lower Basalt Fm., as well as alluvial carbonate and basaltic pebbles that experienced extensive mechanical reworking.

The Clay Series Fm. is contemporaneous to the Umm Sabune Conglomerate Fm. (Figs. 2 and S7). The grain size of both formations decreases upwards as well as towards the depocenters of each basin. The geographic coverage of these formations defines the present spatial extent of basins B2-6 (Fig. 3). The Clay Series Fm. appears at the center of B2B7. In places, it directly overlays the Lower Basalt Fm. (e.g., Taanach 4 borehole; Fig. S3, GE). Its thickness is relatively constant along the axis of the central basins B2 $(400 \mathrm{~m})$ and B4 $(200 \mathrm{~m})$, and it reduces towards B6. In more peripheral areas it ranges around tens of meters (Figs. 8, 9, 11, S1-S6; Table 1). The thickness differences may point to differential subsidence during deposition.

The Lower Basalt Fm. is covered by three younger formations: Bira Fm., Gesher Fm., and locally by the Cover Basalt Fm. (Fig. 2). Seismic resolution does not allow to us differentiate between the Bira Fm. and the Gesher Fm., so these two units are generally termed the Bira Fm. in seismic profiles shown here. The Bira Fm. consists mostly of marls, but also of marine and lacustrine limestones, gypsum, and salt. Its thickness ranges between 0 and $200 \mathrm{~m}$ (Figs. 9 and S5). The Bira Fm. also overlies the Umm Sabune Conglomerate and Clay Series fms. in places (Figs. 2, 5, 8-9, 11, S1, and S4-S6). In seismic data the Bira Fm. appears as a continuous set of reflectors detectable across the basins (Figs. 5 and S4), even in folded and faulted regions (Figs. 8 and 11). Reflectors at the base of the formation onlap an unconformity (Figs. 5, 8, S2, and S4). The top of the Bira Fm. is an unconformity surface (Fig. S4). In places, it is overlain with paraconformity by the Cover Basalt Fm. (Fig. 9). The Bira Fm. is missing over topographic and structural highs (Figs. 5, 9, and S5).

\subsection{Faults}

Three types of faults appear in the database: (1) major marginal faults that bound the southern Galilee basins from north and south; (2) faults dividing between basins, subvertical to the basin axis (their orientation ranges from NE to $\mathrm{NNE}$ ); and (3) throughgoing faults that cross the basins. The current study focuses on the first two types, while the third is at the center of Wald et al. (2019).

\subsubsection{Major faults}

Three major marginal faults define the southern rim of the southern Galilee basins. In the NW, the Carmel fault downthrows B1 by $\sim 1500 \mathrm{~m}$. Further ESE, a series of normal faults includes the Yoqne'am fault, whose downthrown side is B2. The throw decreases southeastwards from $\sim 200 \mathrm{~m}$ to $\sim 50 \mathrm{~m}$ (Figs. 7 and 10c, GE). The trace of Yoqne'am fault diminishes to the SE until it intersects with Gideon and Hayogev faults in the Megiddo region (western margin of B4-5; Fig. 8). The Umm El Fahm fold plunges NE towards B5, where it appears at a depth of 150-200 m below the surface (Fig. S9). Given the poor seismic imaging, a southern bounding fault is marked as suspected (Figs. 10b, c, S10, and S11). However, this discontinuity of reflectors may be ascribed to an apparent structural throw, termed Dotan flexure herein (Figs. 10c, 13, and S10), between the Umm El Fahm anticline (Figs. 3, S10, and S11) and Shekhem syncline (Figs. 3 and S9) of the upper Cretaceous Syrian Arc fold belt (Fig. 3).

The amount of displacement increases again along the Gilboa fault in the southeast. The Gilboa fault extends from the middle of $\mathrm{H} 2$ southeastwards (Figs. 10, S9, and S11). In the NW the Gilboa fault appears in the subsurface of northern B5, where the entire package of reflectors of the basin fill is dipping northwards towards B4. It downthrows B4 by $400 \mathrm{~m}$ relative to B5. The fault downthrows B6 about the Gilboa block footwall (Figs. 7 and S11, GE). The fault is detectable across the shallow subsurface up to the seismic datum (mean sea level) and exposed in places. This suggests it was active at least through the Plio-Pleistocene. In the east, the Gilboa fault also appears in the subsurface of B7, where it forms a flower structure, attesting to a lateral component of displacement. Vertical displacement along the fault is in the range of $100 \mathrm{~m}$ (Figs. 10 and S11). In the southeast, Tayassir, Bardala, and Bezeq faults bound B7 from the south (Figs. 10, S9, S11, and S14). These faults divide between the basin and the NNE-trending Faria anticline that plunges from the south. At the eastern boundary of the study area, DSF truncates the eastern part of B7 (Fig. S14).

The northern border of the Galilee basins is the E-Wtrending Bet Hakerem fault system (including Zurim escarpment) and Ahihud fault (e.g., Matmon et al., 2003; Schatther et al., 2006b; Figs. 3 and 10c). The Neogene basins mapped here pinch out northwards and do not reach these 

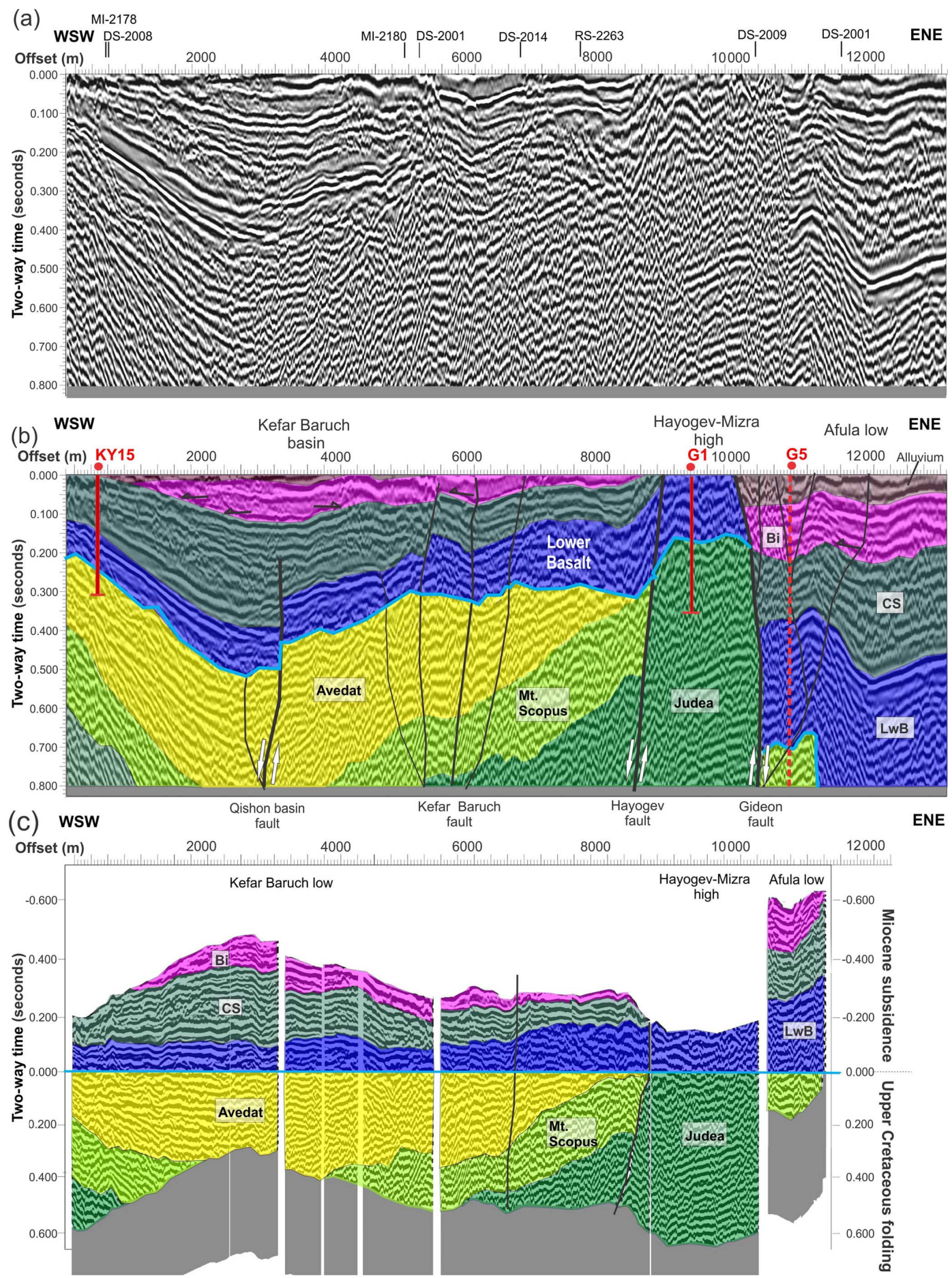

Figure 5. (a) Multichannel seismic reflection profile line MI-2187 crossing the basin axis (location: Fig. 3). (b) The RTS horizon (celeste) divides pre-truncation from post-truncation sediments. The Hayogev-Mizra horst (HMH) intervenes between Kefar Baruch and Afula Neogene basins. Cretaceous units at the syncline were interpreted using intersecting and overlapping deeper seismic profiles from the DS series (see Fig. S3). Boreholes KY15 - Kefar Yehoshua 15, G1 - Gideon 1, and G5 - Gideon 5, projected by 1 km from the south (location: Fig. 3b, GE). Uppermost unit (gray): alluvium. (c) Same profile; flattening of the celeste horizon (RTS) to image the truncation. The flattening tool enables a comparison between predating and postdating sedimentary stacks. Flattening the RTS in the seismic software hints at RTS predating and postdating main processes. For example, in Kefar Baruch basin, Cretaceous folding shown by a syncline predates the RTS, while Neogene subsidence, shown by an accumulation of Neogene sediments, postdates the RTS. Bi - Bira Formation; CS - Clay Series; LwB Lower Basalt Formation. Groups: Avedat Group; Mt. Scopus Group; Judea Group. Vertical exaggeration: $\times 5$. 
Table 1. Marked thicknesses of the Lower Basalt Fm.

\begin{tabular}{llllll}
\hline $\begin{array}{l}\text { Data source } \\
\text { (well name, seismic data, reference) }\end{array}$ & $\begin{array}{l}\text { Associated } \\
\text { basin }\end{array}$ & $\begin{array}{l}\text { Thickness } \\
(\mathrm{m})\end{array}$ & $\begin{array}{l}\text { Base } \\
\text { reached? }\end{array}$ & $\begin{array}{l}\text { Basin } \\
\text { floor }\end{array}$ & Figure \\
\hline $\begin{array}{l}\text { Poriyya type section; Shaliv (1991); } \\
\text { Schulman (1962) }\end{array}$ & B10 & 750 & No & $\begin{array}{l}\text { Senonian } \\
\text { Figs. 8 and 9 in Shaliv (1991); } \\
\text { location: Figs. 3, 10b, GE }\end{array}$ \\
\hline $\begin{array}{l}\text { Gideon 5 } \\
\text { Bira 3 }\end{array}$ & B4 & 630 & No & Senonian Fig. 5, GE \\
$\begin{array}{l}\text { Shadmot Devora } \\
\text { Belvoir 1 }\end{array}$ & B8 & 450 & No & Eocene & GE \\
\hline Seismic data & B6-7 & 660 & Yes & Eocene & GE, Fig. 6 \\
& B7 & 1000 (inter-fingers with & Yes & Senonian Figs. 9 and 11 & Figs. \\
\hline Inbar (2012) & Hordos Formation) & & No & Senonian & \\
\hline
\end{tabular}

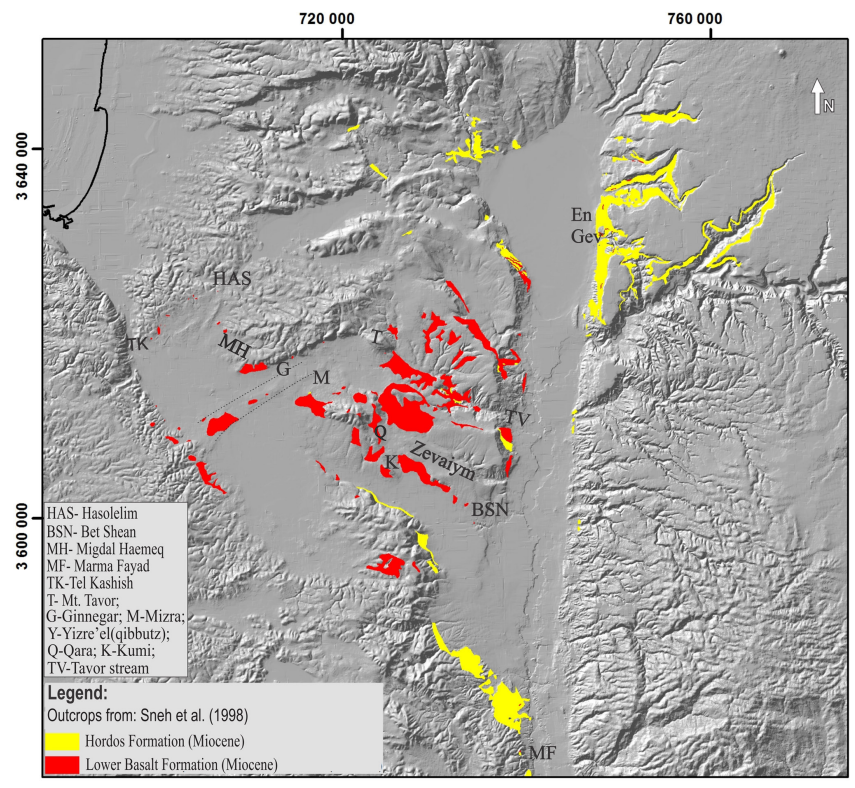

Figure 6. Location of the Lower Basalt Formation and Hordos Formation outcrops. The westernmost outcrop is along the eastern margins of H1 (location: Fig. 3; DEM - Sneh et al., 2000b).

faults. Therefore, the E-W-trending Tur'an, Bet Netofa, and Bet Hakerem valleys are excluded from the current analysis (locations: Fig. 3). A series of NW- to W-trending faults divides between the latter E-W valleys and the Neogene basins. The western segment of Bet Qeshet fault borders H1 from the north. Further east, three step faults downthrow B2 (Zarzir, Timrat, Nahalal faults; Figs. 10c, 11, and S2). The NE-trending Nazareth fault downthrows B3 southwards, while B3 fill is dipping to the north (Fig. S4). East of B3, the Tavor horst (T in Fig. 6) is uplifted along the eastern segment of Bet Qeshet fault (Figs. 3, 10c, 12; GE). The fault divides the horst from the Sirin-Qama block (B9 - Fig. 3, location of fault: Fig. 10c, GE). Neogene exposures extend up to the northeastern corner of the southern Galilee basins (Figs. 6

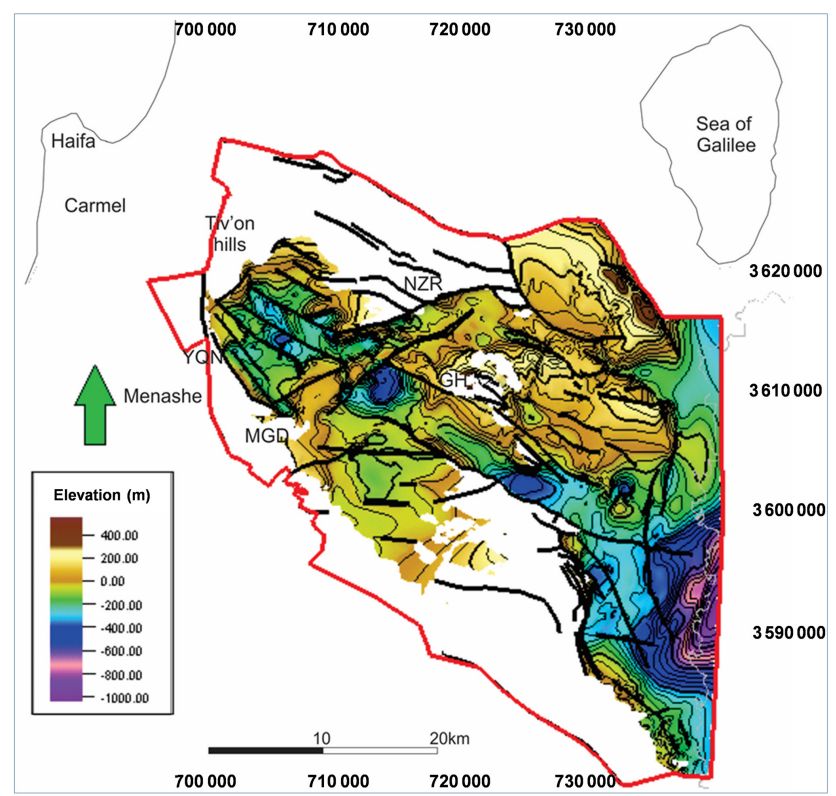

Figure 7. Structural map of the top of the Lower Basalt Formation surface. Note that the lowest areas strike NW. GH - Givat Hamore, MGD - Megiddo, YQN - Yoqne'am, NZR - Nazareth.

and 10). However, in this area, the delimitation of the southern Galilee basins is less clear due to later displacements.

\subsubsection{Secondary faults}

A series of NNE- to NE-trending normal faults divide between the basins and structural highs of the southern Galilee. The faults are nearly perpendicular to the axis of the basin complex. Seismic data show that displacements across these faults are mainly vertical with a horizontal component. Regional numerical modeling of Lyakhovsky et al. (2012), followed by a review of rift-transform interaction adjacent to continental margins (Segev et al., 2014), has predicted riftperpendicular features. Locally, these faults, structural highs, 


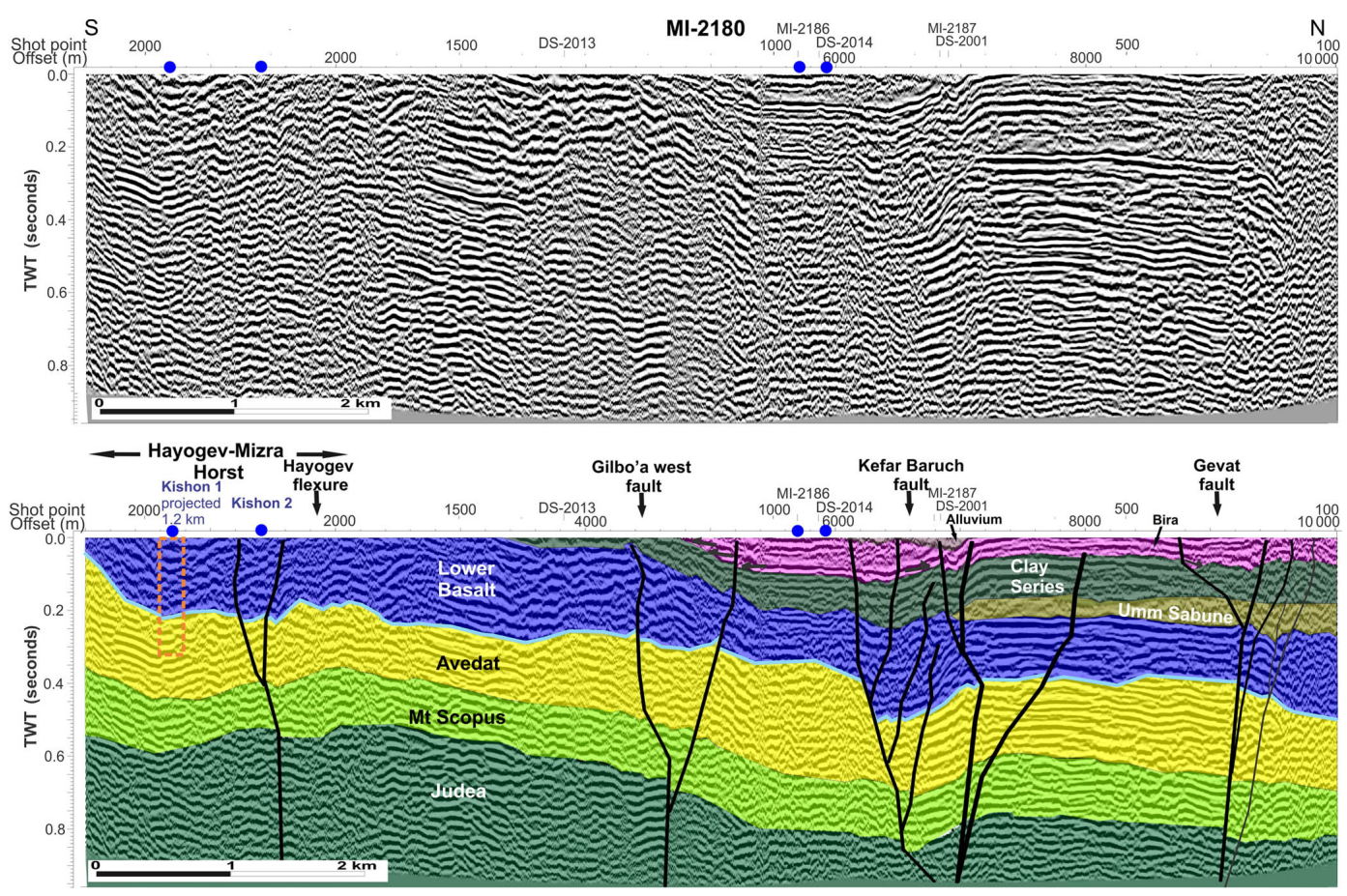

Figure 8. Multichannel seismic reflection profile line MI-2180. Kefar Baruch basin (B2) and Hayogev-Mizra horst (HMH) are sheared by faulting and folding. Vertical offset alongside folding on fault branches deforms the Clay Series, Umm Sabune, and Bira formations. Gevat fault suggests a horizontal offset due to its near-vertical fault plane and $1 \mathrm{~km}$ wide flexures (see also Fig. 11). The thick Lower Basalt Formation on the south suggests a volcanic source in the HMH area (see also Fig. 10). This profile cuts the primary deformation zone and its uplifted southern shoulders - HMH. Celeste horizon - RTS. Orange dashed rectangle - projected location of the Kishon 1 well. Arrows depict onlap of the Bira Fm. on the Clay Series. Vertical exaggeration: $\times 2.5$.

and basins between them are evident from the structural map of the top of the Avedat Gr. that makes up the floor of most of the basins (Fig. 12). The following paragraphs describe the division along the major axis from NW to SE.

The structural and topographic transition between $\mathrm{H} 1$ and B2 occurs along a lineament associated with Sede Ya'akov and Aloney Abba faults. These faults are derived from the geological map (Sneh et al., 1998; Segev et al., 2006) since a seismic profile does not intersect them. These faults expose fragmented outcrops of the Lower Basalt Fm., as well as a chain of localized springs (Figs. 3, 10c; GE). The intersection between Sede Ya'akov and Gilboa west faults in the WSW of B2 is a fracture zone (Tel Kashish; location: GE; Figs. 7, 10, 11, 12, and S12). Hayogev fault bounds B2 in the east, defining the transition to the NE-trending H2. The Lower Basalt Fm. forms a westward-dipping monocline above the fault (Fig. 5).

The $\mathrm{H} 2$ horst is topographically elevated by several tens of meters above $\mathrm{B} 2$ and $\mathrm{B} 4 . \mathrm{H} 2$ plunges to the NE into the subsurface of B3, partially dividing B3 into two sub-basins (Figs. 5, 6, S1; GE). Plio-Pleistocene sediments are absent from the top of H2. The Lower Basalt Fm. overlies an erosional unconformity of the top of the Judea Fm. (Gideon 1 and 4 wells; location: GE; Figs. 5 and 9) and Mt. Scopus Gr.
(Gideon 3 well; Figs. 5, S3, S4, S10; location: GE). Gideon fault bounds $\mathrm{H} 2$ from the east, downthrowing B4. Normal displacement along this fault is $\sim 100 \mathrm{~m}$ in its northern and southern margins. It reaches $\sim 500 \mathrm{~m}$ in the middle (main axis of the basins). Correlations between seismic data and Gideon 1, 2, and 5 wells (Figs. 5, 9, and S5; GE) show uneven thickness between the fault flanks, suggesting that it was active several times during the middle and late Miocene, at least until the end of deposition of the Bira Fm. (Figs. 5, 7, 9, and S5).

Three structural elements separate B3 from B4. Afula fault vertically throws Lower Basalt Fm. reflectors northward by approximately $200 \mathrm{~m}$ (Figs. 7 and 10). East of the fault the volcanic Givat Hamore and Ein Dor blocks separate B3 from B4. (Fig. 10, location: Fig. 7, GE). Gideon 5 well, located along the margin of B4, crossed $980 \mathrm{~m}$ of Neogene basin fill and did not encounter the base of the Lower Basalt Fm. This suggests that vertical displacement across Gideon fault occurred during the mid-Miocene. The displacement took place concurrently with dike intrusions and uplift of Givat Hamore and Ein Dor blocks (Figs. 7 and 10).

Gilboa fault defines the boundary between B4 and B5 to the south, off the axis of the southern Galilee basins. Data indicate that the B5 fill thickens northwards towards Gilboa 
fault (Figs. 12 and S16). B5 is bounded by $\mathrm{H} 2$ in the west and $\mathrm{H} 3$ in the east. Avital fault crosses the NW corner of B5 (Figs. 10c and S10). Displacements along this subvertical fault are mainly horizontal. They are associated with branching into secondary faults and local folding (Figs. S10 and S16).

The elongated B6 basin extends along the main axis of the southern Galilee basins, north of the Gilboa fault. The Lower Basalt Fm. covers the WNW margin of H3. An intermediate graben hangs as a step between B6 and H3, faulted along Gilboa fault (Shaliv, 2003, 2005). Seismic data show that the northern limit of B6 is downthrown along Hashita and En Harod faults relative to the Hashita-Geva-Zevayim block (Figs. 7, 10, 12, and 13). Subvertical normal faults downthrow B7 relative to the eastern flank of $\mathrm{H} 4$ and the HashitaGeva block (Figs. 9, 13, S11, and S13). Bet She' an fault is the easternmost of this series. It downthrows the Lower Basalt Fm. $200 \mathrm{~m}$ on its eastern side (Fig. S14). However, the basin fill thickens and tilts to the east, where its original structural boundary is unclear. Similarly, the structural transition from $\mathrm{B} 7$ northwards into B8 is vague.

\section{Discussion}

Integrated analysis of the geological-geophysical dataset shows the structural development of the original flat Oligocene to early Miocene RTS (Fig. 2; Avni et al., 2012) into a series of extensional basins (grabens and half-grabens). The discussion addresses the development of the basins based on their structure and stratigraphy. It then suggests a classification of the southern Galilee basins at each stage given the regional tectono-stratigraphic events and comparison to similar structures worldwide. These insights are used for understanding the structural development of a failing rift during its final stages.

\subsection{Subsidence of basins}

\subsubsection{First stage (20-9 Ma)}

The first stage of subsidence initiated during the early to middle Miocene. The subsidence occurred mainly near the eastern part of the southern Galilee basins, across B6-11 (Fig. 3). Subsidence and faulting developed while the conglomerate member of the Hordos Fm. accumulated in topographic lows (Schulman and Rosenthal, 1968; Garfunkel, 1989). A composite section crossing the basins along a WNW trajectory shows that Hordos Fm. accumulation in B6-8 was accompanied with normal faulting and folding (Fig. 9). However, remains of the Hordos Fm. are not restricted to the subsiding basins. Their extent is larger than the current northwest array of basins. They appear in sporadic outcrops, such as Marma Fayad and Ein Gev (thickness exceeds 200 m; location: Fig. 6, GE), in various elevations on the northern flank of the Faria anticline, across the tilted blocks of the eastern
Galilee, and across southern B9. The abovementioned evidence suggests that the current shape of the southern Galilee basins was formed by younger deformations, while preceding Miocene basins extended further south of their presentday structure. It also indicates that these remains were displaced by younger faults (Figs. 10 and 12; Shaliv et al., 1991) that were active during the initiation of motion along the DSF (Freund, 1978; Garfunkel, 1981, 1989).

The spatial and temporal provenance of the lower to midMiocene conglomerate of the Hordos Fm. is still debated. Conglomerate accumulation of the Hordos Fm. suggests that basin subsidence predates the Lower Basalt Fm., although in several localities it inter-fingers with it (Figs. 9, S8, and S14). Temporal emplacement is therefore tricky. Outcrop and seismic data from B2 show that normal faults displace a conglomerate unit before the Lower Basalt Fm. accumulated (Fig. 11). Sandler et al. (2004) associate the conglomerate unit to the Bet Nir Fm., suggesting it is concurrent with the Lower Basalt Fm. (17-9 Ma). Our integrative morphostructural analysis bridges the spatial gap between the isolated patches of the conglomerates (e.g., Kafri, 2002; provenance study), suggesting that the Bet Nir and Hordos fms. accumulated at the same time frame. Together they are products of the same paleo-drainage system that extended from the east to the west across the low relief of the Galilee immediately before the subsidence of the basins.

The southern Galilee basins accumulated an up to $650 \mathrm{~m}$ thick section of volcano-clasts and flows of Lower Basalt Fm. during their subsidence (Fig. 10). In general, the thickness of a basaltic unit is expected to increase close to its source. This assumption guided the identification of volcanic sources across the study area. The seismic and borehole database provided evidence for thickness variations and information about lithology. Previous studies provided basalt dating from outcrops and wells, along with mapping of tilted blocks and faults (Fig. 10; GE; Segev et al., 2006; Dicker, 1964; Schulman, 1962; Shaliv, 1991). Integration of the data sources indicate that the basalts arrived through dikes (e.g., Gilboa, Mishmar Haemek), stocks (Givat Hamore), volcanic eruption centers (Kippod, Kochav Hayarden, Tel Agol), and fault planes (Sede Ya'akov, Moledet, Yoqne'am, Sandale, Aloney Abba; Figs. 7, 10, 11, and 12). Baer et al. (2006) dated the eruption at Givat Hamore to $13.5 \mathrm{Ma}$. Geochemical analysis of volcanic products suggests that the lithosphere of the Galilee has been rich with veins that fed the Miocene magmatism (Weinstein, 2000). Some of the volcanic sources (e.g., dikes; Hatzor, 1988; Shaliv, 1991) follow the southern boundary faults of the basins, suggesting a possible connection (Figs. 7 and 10).

During the mid-Miocene, normal displacements along faults facilitated deepening of the basins (Figs. 7, 10c, and 12). The structural signature of the left-lateral displacement along the DSF is enhanced between 12 and $14 \mathrm{Ma}$. Bosworth et al. (2005) suggest that the movement started at $\sim 14 \mathrm{Ma}$ in association with the transition of Red Sea opening. In re- 


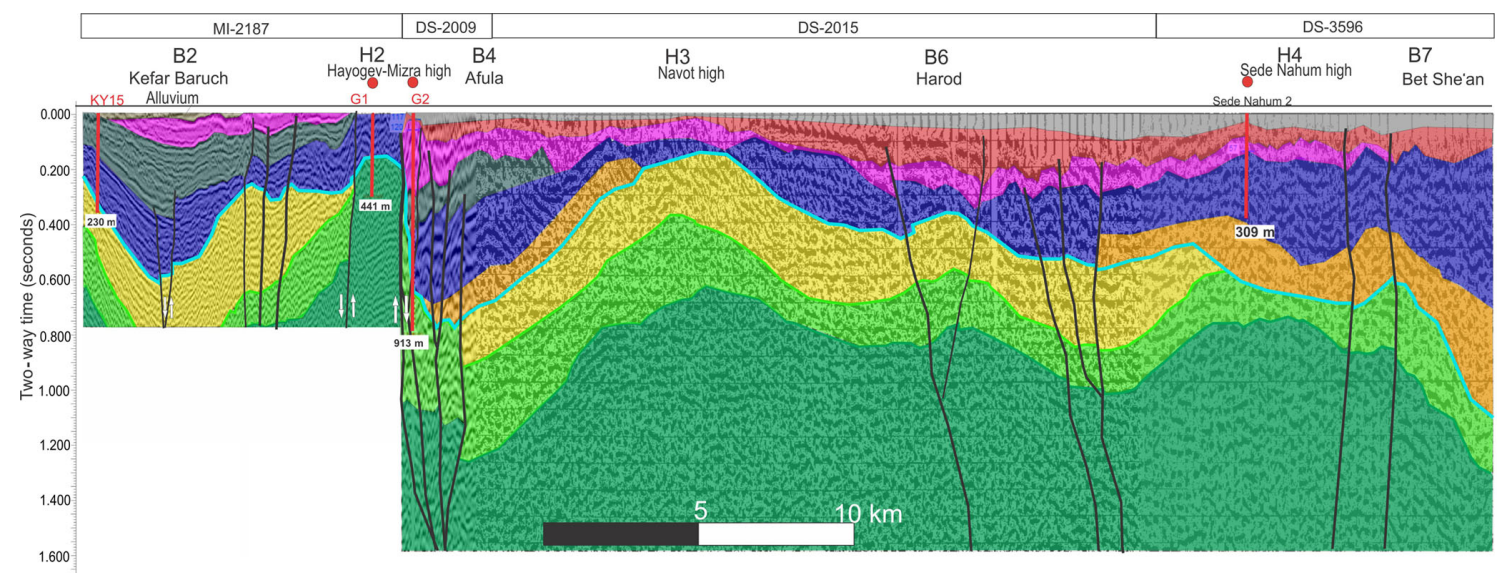

Figure 9. Multichannel seismic reflection profile across basins B2, B4, B6, and B7 (lines MI-2187, DS-2009, DS-2015, DS-3596). The RTS horizon (celeste) divides pre-truncation from post-truncation sediments. The Hayogev-Mizra high (HMH) intervenes between the Kefar Baruch and Afula Neogene basins. Cretaceous units at the syncline (Kefar Baruch, B2) and in the eastern B7 area were interpreted using intersecting and overlapping deeper seismic profiles from the DS series. Location: Fig. 3; unit color code - Fig. 2. No vertical exaggeration.

sponse, the slip along the DSF shifted from a $\mathrm{N} 60^{\circ} \mathrm{E}$ opening motion, perpendicular to the Red Sea axis, to a $\mathrm{N} 15^{\circ} \mathrm{E}$ motion, diagonal to that axis but parallel to the axis of the DSF. Others estimate the initiation of DSF displacement in the study area to $13 \mathrm{Ma}$ (Shaliv, 1991). Northward channeling of the Afar plume (Ritesma et al., 1999; Chang et al., 2011; Hansen and Nyblade, 2013) along with geodetic and structural research (Bellahsen et al., 2003; Bosworth et al., 2005; ArRajehi et al., 2010) suggest a transition in stress regime. Three-dimensional analogue models of the Red SeaGulf of Aden rift system point at an increase of $70 \%$ in the rotational relative motion between Africa and Arabia since $13 \mathrm{Ma}$ (Molnar et al., 2017). This pronounced shift at $13 \mathrm{Ma}$ has left footprints in the Galilee branch.

The association between volcanism and tectonics specifically around $13 \mathrm{Ma}$ appears in several studies across the Arabian Plate (e.g., Bayer et al., 1989; Camp and Roobol, 1992; Ebinger and Casey, 2001). Until 13 Ma volcanic activity closely follows the faulting event. A marked shift in volcanism is noted at $\sim 13 \mathrm{Ma}$. In the western Arabian Plate, volcanic fields renewed their activity after a cessation of 9 Myr (Bohannon et al., 1989; Camp and Robool, 1992; Ilani et al., 2001; Krienitz et al., 2009). In contrast, magmatic activity in the Galilee was relatively continuous. $\mathrm{K}-\mathrm{Ar}$ dating bound the volcanic activity across B2 between 16 and $9 \mathrm{Ma}$ (i.e., the Lower Basalt Fm.; Shaliv, 1991). Further to the east across B6-B11, H3, and Mt. Gilboa, older K-Ar ages of 1715 Ma were retrieved (Shaliv, 1991; 3, 5, 14, 19 in Fig. 10a). Updated ${ }^{40} \mathrm{Ar} /{ }^{39} \mathrm{Ar}$ dates yield a lower limit of $17 \mathrm{Ma}$ for the Lower Basalt Fm. (Rozenbaum et al., 2016; Sandler et al., 2015). Since 13 Ma, volcanism was active across Harrat Ash Shaam, western Arabia, and the Galilee. It was active during the subsidence of the southern Galilee basins and the accumulation of conglomerates.
Integration of all the above evidence indicates that during the first stage an E-W-trending paleo-drainage system developed across the southern Galilee, accumulating conglomerates. Shortly after, this drainage pattern ceased during the relief accentuation due to subsidence of a series of $<10 \mathrm{~km}$ wide grabens and half-grabens. The basins collected conglomerates separately along with the Lower Basalt Fm. The basins subsided along a NW-trending axis (Fig. 12). Within this general trend, some individual basins trend to the WNW and $\mathrm{W}$. These basins continued to sink, extend, and even merge during the transition to the second stage of subsidence.

\subsubsection{Second stage (9-5 Ma)}

Tectonic displacements that acted during the first stage of subsidence continued during the second, along with erosion. A series of blocks and depressions depicted from the structural map of the Lower Basalt Fm. points at the continuance of vertical motions. Basins continued to subside, forming local topographic lows that accumulated the erosion products. Conglomerates of the Umm Sabune Fm. settled close to the edges of the basins (Figs. 8, S2, and S7). Their composition includes pebbles of Lower Basalt Fm. as well as older carbonates (Sandler et al., 2004). Grain size of the conglomerates decreases upwards (Schulman, 1962), indicating a moderation of tectonic activity along the rims of the basins with time. Umm Sabune Fm. outcrops tilt southwards along the northern rim of B2 (Kafri, 2002). They consist of $200 \mathrm{~m}$ of the Shokek 1 well drilled in a western marginal graben of B7 unconformably covering Avedat Fm. (location - GE), occur at the northern plunge of the Faria fold at the southern B7 border (Shaliv et al., 1991), and compose the upper part of B8-9 inter-fingering with the Bira Fm. (see below). The Umm Sabune Fm. appears to thicken within the incised channels that drain B6. The thickening could result from two 


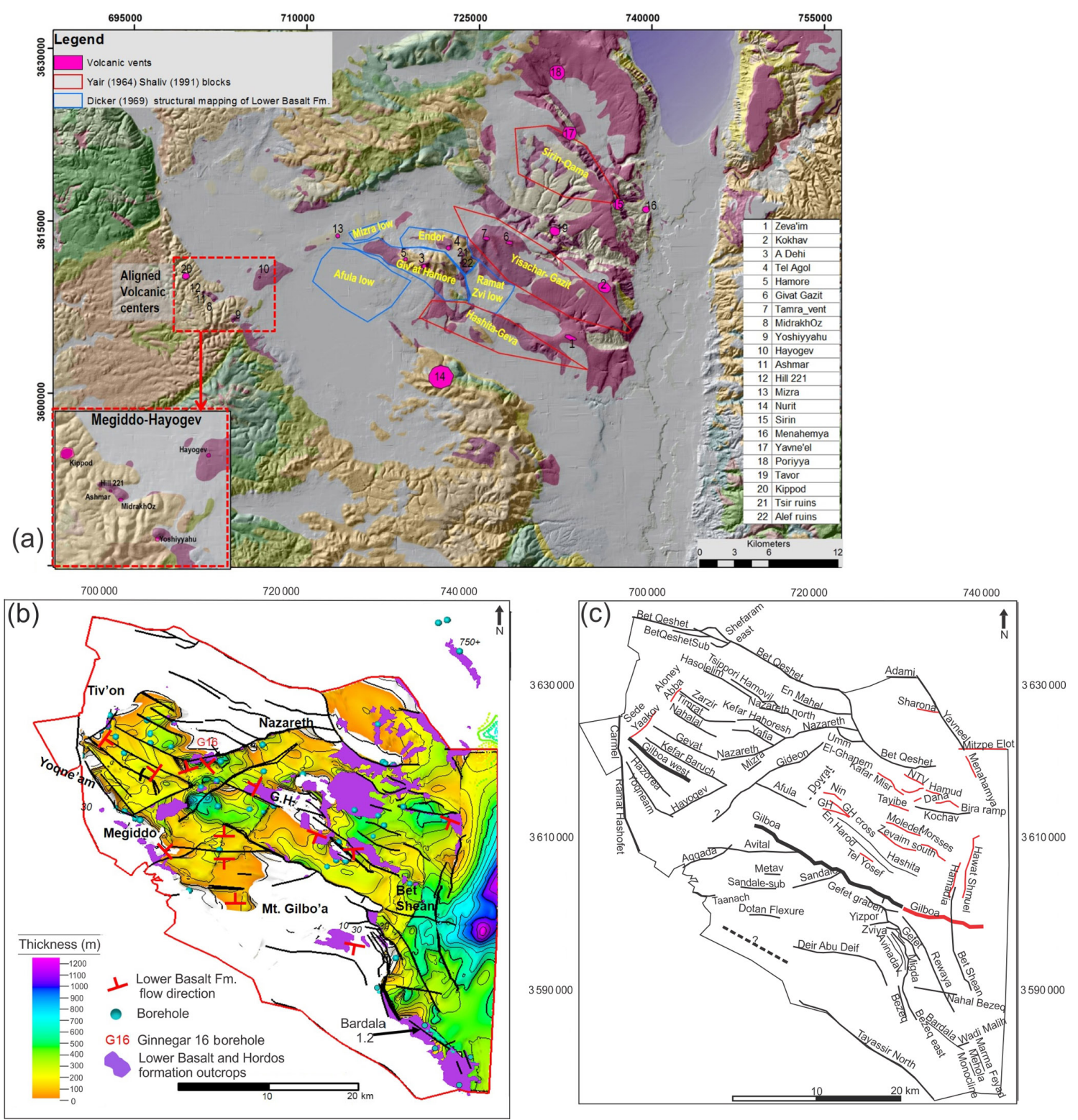

Figure 10. (a) Inferred volcanic sources for the Lower Basalt Formation. Miocene edifices interpreted by Yair (1968), Dicker (1969), and Shaliv (1991) are ascribed to normal faulting synchronous with Lower Basalt Formation flows. Part of the sources was interpreted using potential methods (Segev and Rybakov, 2011). (b) Isopach map of the inter-fingering Lower Basalt Formation and the Hordos Formation. Locally, the latter predates the former. Contour spacing: 100 m. G.H. - Givat Hamore (c) Faults within the study area. Red lines: post-Avedat Group (lower to middle Eocene) faults. Black fault lines: offset all surfaces within the scope of this study from top of Judea Group to top of Lower Basalt Formation (upper Cretaceous to Miocene).

factors. Syn-tectonic magmatism allowed the Lower Basalt Fm. to accumulate within subsiding basins, on the one hand, whereas other parts of the formation were uplifted across their rims. The basins deepened while their margins were gradually elevated (Dicker, 1964). Therefore, elevated terranes and basinal margins were the provenance of the Umm Sabune Fm. Ongoing subsidence of B7-8 during the middle to late Miocene facilitated the accumulation of a thick section of Umm Sabune Fm. near the margins of the basins (e.g., Bet Yosef, Neve Ur, and Zemach wells; Fig. 8, Fig. S7; locations: GE). The Clay Series Fm. was deposited within their depocenters (B2-6; Figs. 8, 9, 11, S1, S2, and S4-S6). The Clay Series Fm. has been preserved since most of the tectonic activity focused on the edges of the basins. As evidenced by the presence of tens of water wells, this formation is verified as a local aquiclude (Wishkin, 1973).

Deposition of the Bira Fm. occurred during the volcanism that produced the Intermediate Basalt Fm. This volcanic for- 

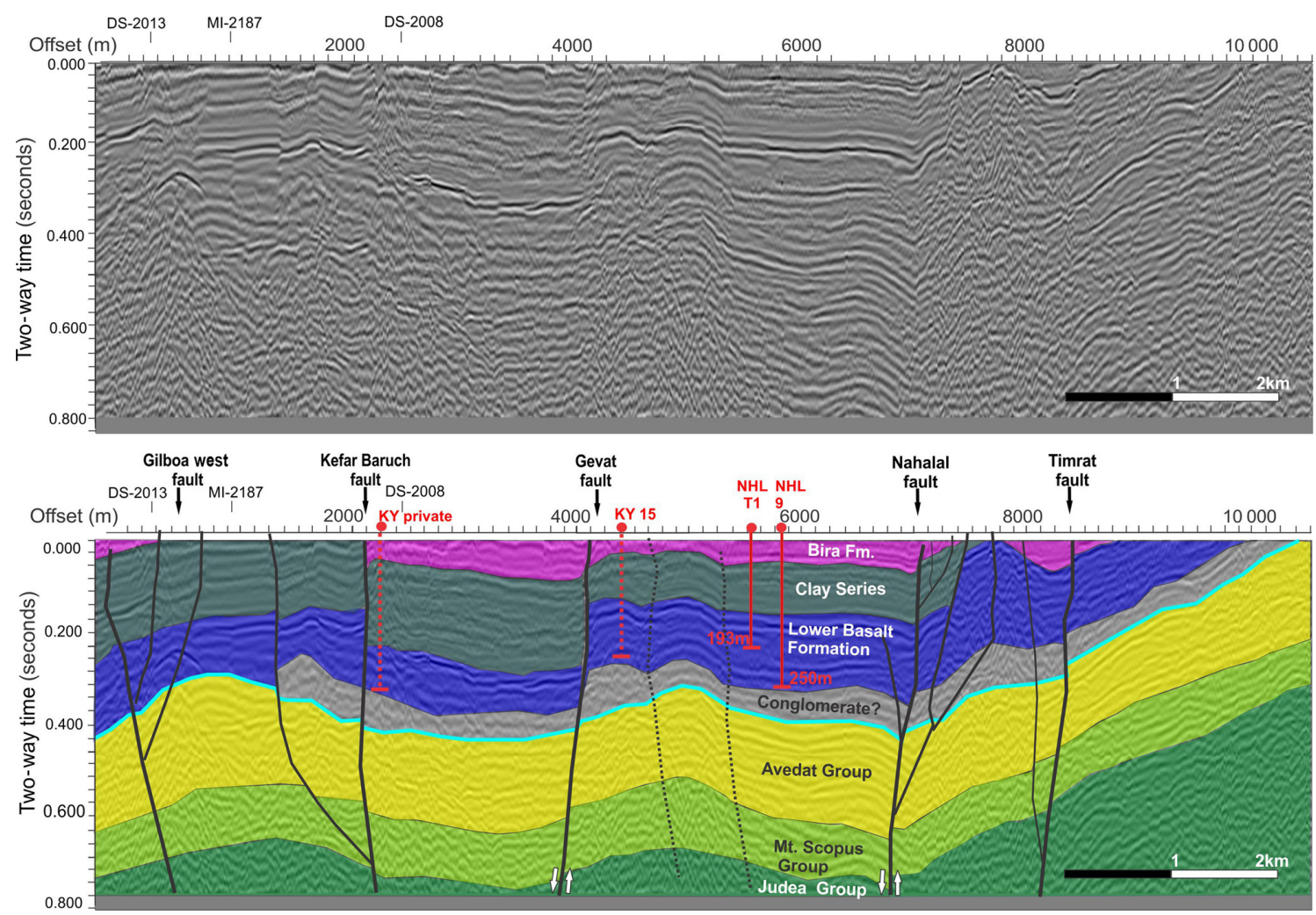

Figure 11. Multichannel seismic reflection profile line MI-2178. Strike-slip faults with a normal component in the frame of Plio-Pleistocene lateral shear adjacent to Mt. Carmel and Tiv'on blocks. Normal faulting vertically offsets basin fill units. Post-Bira Formation folding (postdating uppermost Miocene-Pliocene) is assigned to the strike-slip shear on the originally normal faults. A paleo alluvial fan, predating the vertical offset, is depicted by the Clay Series. Celeste horizon - RTS; dashed lines - projected wells. NHL - Nahalal; KY - Kefar Yehoshua. Location: Fig. 3; unit color code - Fig. 2. Vertical exaggeration: $\times 3$.

mation mainly follows faults (Shaliv, 1991), and due to its minor occurrences (thin sections of a few to tens of meters) seismic resolution does not permit its interpretation. It occurs cross H3 (Shaliv et al., 1991), along Rewaya and Gefet faults (Figs. 9, S5, S8, and S14) in B7-10, and the central Jordan Valley (Schulman, 1962; Rozenbaum et al., 2016). With time, accumulation of the Bira Fm. moderated the rugged relief of the Galilee until it became almost flat at the end of the Miocene (Fig. S5). The outcrops of the Bira Fm. appear today close to faults that were active during the second stage of subsidence and in places cover these faults. This evidence suggests that the Bira Fm. recorded the cessation of subsidence of the southern Galilee basins. The cessation might be associated with a short-term tectonic quiescence across the Sinai subplate and its nearby Levant margin, allowing marine transgressions to cover the low relief of the southern Galilee.

Previous studies suggest that part of the Bira Fm. accumulated across the southern Galilee basins during one or more marine transgressions during the upper Miocene (Blake, 1935; Schulman, 1962). Shaliv (1991) suggests the transgression occurred between 7 and $6 \mathrm{Ma}$ (Tortonian), whereas the global eustatic record does not contradict additional marine intercalations between 5.4 and $5.25 \mathrm{Ma}$ (e.g.,
Haq et al., 1987; Müller and Hsu, 1987). This deduction is also supported by marine megafauna (Shaliv, 1991), $O s$ trea lumachelle unusual facies in outcrops of southern B9 (Schulman, 1962), and lithological resemblance of the latter and those of the southern Galilee basin marine succession (Michelson and Lipson-Benitah, 1986). The transgressions probably arrived from the west (Mediterranean) since at that time the topographic valley along the $\mathrm{N}-\mathrm{S}$-trending DSF already existed (Fig. S14; Segev et al., 2017). In addition, lithology of the Bira Fm. shows a distinct marine to estuarine (saline to brackish) facies shift from west to east (Dicker, 1964). The change occurs north of B6 (B7-8, along Moledet-Bira in the Bira (2) and Shadmot Devora (4) wells; see GE). Gvirtzman et al. (2011) describe a lateral facial shift during the late Miocene (Fig. 13 in Gvirtzman et al., 2011): the Pattish Fm. represents the first facies of a continental shelf (i.e., marine) environment. The transition to the second lacustrine floodplain facies of the Bira Fm. is located on the eastern flank of H1, next to the intersection between Sede Ya'akov and western Gilboa faults in Tel Kashish (Figs. 3, 10c, and S12; Zilberman and Sandler, 2013). Further east, the third facies of the Bira Fm. is represented by the land- 


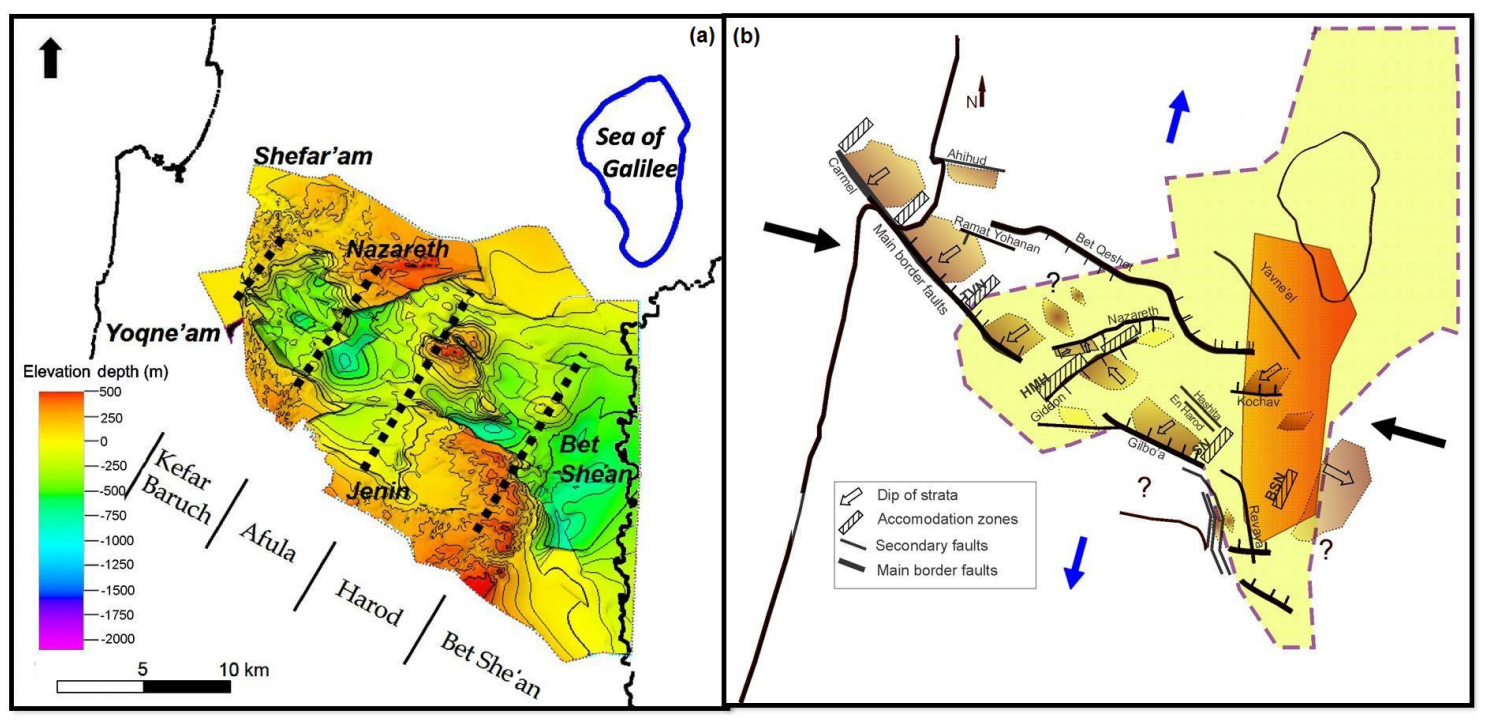

Figure 12. Structure of the study area during the Cenozoic. (a) Structural map of the top Avedat Group. Dashed lines portray the structural highs (H1-4 in Fig. 3a). The current structure of the Galilee is a product of two main subsidence phases shown in (b). (b) Aerial extent of the first subsidence stage (20-9 Ma) is outlined in light yellow. Dark orange - pronounced subsidence during the first stage, overlapping the current Dead Sea fault valley. The second subsidence stage (9-5 Ma) is outlined by a series of NNE-trending basins perpendicular to the major axis of basins from the first stage. Darker brown - pronounced subsidence. The second-stage stress field is depicted by black arrows (compression) and blue arrows (extension). Bounding normal faults also exhibit a lateral component. HMH - Hayogev-Mizra high, TVN Tiv'on, SN - Sede Nahum, BSN - Bet She'an.

locked lake environments of the Sedom Fm. (i.e., along the Dead Sea fault).

During the late Miocene, Tortonian episodic marine transgressions filled the southern Galilee basins. Saline conditions developed in separated water bodies as evident from the accumulation of laminar marls and evaporates (Bira and Sedom fms.; Shaliv, 1991; Fig. 17d in Segev et al., 2017). Clean gypsum crystals found at the outlet of the Tavor stream are associated with a proximal lagoon depositional environment (location: Fig. 6; GE). Rozenbaum et al. (2016) suggest that the gypsum crystals formed before the onset of the Messinian salinity crisis, i.e., prior to $5.96 \pm 2 \mathrm{Ma}$ (Krijgsman et al., 1999; Manzi et al., 2013). Our data show that chalks and limestones were deposited in shallow basins at the Yisachar and Poriyya area, while conglomerates accumulated along the rims of the basins (Fig. S15). This flooding is contemporaneous with the onlap of the Pattish Fm. reefal limestones along the Israeli coastal plain.

At the end of the second stage, shallow brackish-water lakes occupied the topographic lows above the basins. Limestones and chalks of the Gesher Fm. accumulated in lakes (Shaliv et al., 1991; Rozenbaum et al., 2016). The thickness of the Gesher Fm. merely reach tens of meters, slightly above the seismic resolution limit. The Bira and Gesher fms. sealed the southern Galilee basins and formed a relatively flat relief. Similar to the RTS at the base of the basins, the relatively flat top of the Bira and Gesher Fm. serve as a marker for tectonic activity that deformed the study area during the Plio-Pleistocene.

Data presented in this study suggest that the uplift of Mount Carmel, Tiv'on, and Shefar'am occurred close to the end of the second stage, between 5 and $6 \mathrm{Ma}$ (Figs. 3 and 12). The uplifts placed topographic barriers between the Mediterranean Sea and the inland lakes, diverting possible marine transgressions to regions south of the Galilee. These observations stand in line with Shaliv (1991). Gvirtzman et al. (2011) suggest that the Carmel area was submerged under marine conditions before the upper Miocene. They base this deduction on a single outcrop located in Bet Rosh that contains a continuous marine succession from the Eocene to midMiocene. These authors accept the possibility that the Galilee was exposed and claim that it resembled the Carmel in the timing of the initiation of vertical displacements during the upper Miocene. The integrative geological-geophysical data presented here show the situation differently. Our results attest to lacustrine-fluvial infill hundreds of meters thick that accumulated during the early and mid-Miocene displacements, while tectonics were active (Figs. 7-12).

In summary, the pattern of subsidence of separated and localized basins continues from stage one to stage two. However, during the second stage, the basins also elongated along a NNE trend, while keeping the elevated structural highs in between (Fig. 12). Numerical modeling of deeper sections of the lithosphere predicted such a relief pattern of rift axis perpendicular faulting (Lyahovsky et al., 2012; Segev et al., 
2014). The subsidence extended beyond the area studied here into the regions that were uplifted and eroded during the PlioPleistocene, for example over $\mathrm{H} 3$ and the tilted blocks of the eastern Galilee (Figs. 3, 6, and 7).

\subsection{Tectonic classification of the basins during the two stages}

The Galilee basins developed during the Neogene due to two major structural processes. An extensional regime during the first stage (20-9 Ma) formed the Galilee basins. The thinning of the Lower Basalt Fm. to the northwest (Figs. 6 and 10) supports the diminishing of volcanic sources as well as shallowing of the basin floor in that direction. The Lower Basalt does not cross H1 (Fig. 3) to the west. This trend suggests a reduction in regional extension towards the continental margin in the west, previously assessed by Freund (1970). At this stage, the structure of the basins and their dimensions are equivalent to intraplate grabens and half-graben basins that form during intracontinental rifting (Evison, 1959; Bosworth, 1994; Busby and Ingersoll, 1995; Allen and Allen, 2005; Morley et al., 2004). Previous studies showed the development of the Irbid (also referred to as Qishon-Sirhan or Azraq-Sirhan) rift during the OligoceneMiocene in a northwesterly direction (Shaliv, 1991; Schattner et al., 2006a; Segev et al., 2014).

The second stage of subsidence (9-5 Ma) marks a transition of the extensional stress regime into transtension along a primary NNE direction and a secondary WNW direction. Basins subsided vertically and extended perpendicularly to the principal axis of the first-stage basins, while uplifted blocks (i.e., structural highs) separate them in a NNE direction (Fig. 12). The highs are accommodation zones, structurally equivalent to the intervening block separators between basins along the East African Rift (Bosworth, 1985; Bosworth et al., 1986; Rosendahl, 1987; Ebinger et al., 1987, 1989; Burgess et al., 1988; Morley et al., 1990). These cited studies also show that basins along a forming rift accumulate sediments while tectonic subsidence is in action. As a system, some of these rifts may succeed and continue to open, while others fail. The two stages recorded here occurred alongside the initiation of motion along the nearby DSF plate boundary.

Interaction between the Dead Sea fault and the Irbid rift is depicted by the deep depocenter of the Bet She' an basin (B7) at the then junction area (Fig. 7; pre-lateral displacement on the Dead Sea fault). Volcanism initiation is also suggested as $17 \mathrm{Ma}$ for the Galilee (Rozenbaum et al., 2016; Shaliv et al., 1991). Transform-rift interaction adjacent to the continental margin is manifested by NW-striking faults within the Galilee and NE-striking faults within the Golan Heights (location: Fig. 3). This process signifies the crossing of the Irbid rift into the other side of the DSF (Fig. 1b; Segev et al., 2014). Our study supports the numerical modeling of Segev et al. (2014) by showing that the active rifting of the Irbid rift on the western side of the DSF succeeded in opening basins by cutting across the Levant continental margin (Fig. 1b).

\subsection{Structural stress field transitions along the plate boundary}

The ongoing Afro-Arabian and Eurasian convergence (Letouzey and Tremolieres, 1980) induced three major stress regimes across the Galilee. (1) The Syrian Arc compressional stress regime (Krenkel, 1924) produced a WNW shortening during the Turonian (Eyal, 1996; Eyal et al., 2001). Compression-related folds plunge north towards the CarmelGilboa trajectory, are buried in the subsurface of the southern Galilee basins, and are exposed again across the northern Galilee (Fig. 3). (2) The Red Sea extensional regime $\left(\mathrm{N} 60^{\circ} \mathrm{E}\right.$ extension) prevailed during the Oligocene to the early Miocene (Steckler and ten Brink, 1986; Khalil and McClay, 2002, 2016; Younes and McClay, 2002; Bosworth et al., 2005). It resulted in the coeval opening of the parallel Red Sea and Irbid rifts (Shaliv et al., 1991; Schattner et al., 2006a). The $\mathrm{N} 60^{\circ} \mathrm{E}$ extension (McClay and Khalil, 1998; Younes and McClay, 2002; Bosworth et al., 2005) later shifted during the Neogene (Garfunkel and Bartov, 1977) to the NNE (N15 ${ }^{\circ}$; Bosworth et al., 2005). The NW-trending faults that developed across the study area are part of larger fault systems extending across the western Arabian Plate (Fig. 1). Fault systems of the Suez-Red Sea (Steckler and ten Brink, 1986), Irbid (Schattner et al., 2006a), and Karak (Bender, 1974) reactivated traces of the Precambrian Najd fault system (Stern, 1985, 1994; Agar, 1987; Fig. 1). Our data show that the Red Sea regime provided sufficient conditions for the first stage of subsidence of the southern Galilee basins at the northwestern tip of the Irbid rift. The failure of this rift during the early to middle Miocene is closely associated with the emergence of the third, Dead Sea, stress regime (Schattner et al., 2006b; Segev et al., 2014).

Convergence between the Arabian and Eurasian plates transformed into collision and slowed down during the midMiocene (14-12 Ma). This short recess resulted in tectonic quiescence in the Suez portion of the Red Sea rift (Bayer et al., 1989), the southern equivalent of the Galilee basins. Between the two rift systems (i.e., Suez and Galilee), the Negev (southern Israel) ceased to subside (Zilberman and Calvo, 2013; location: Fig. 1), while the Judea region was elevated by $400 \mathrm{~m}$ above the Miocene coastline (Sneh and Buchbinder, 1984; Bar, 2013; location: Fig. 1). During the same time window, a numerical simulation shows a depression that subsided along the Irbid rift NW-trending axis, still not entirely affected by the displacement along the intersecting DSF (Lyakhovsky et al., 2012; Segev et al., 2014). This depression extended from the Irbid structural low in the east (NW Jordan) to the Beteha, Sea of Galilee, and Kinarot basins in the west (location: Fig. 1b; Segev et al., 2014). 
The tectonic transition between the Red Sea and Dead Sea stress regimes was accompanied by an up to $50 \%$ decrease in the relative velocity of the African plate around $11 \mathrm{Ma}$ (Reilinger and McClusky, 2011) and a geometric rearrangement of the plates around $9 \mathrm{Ma}$ (McQuarrie et al., 2003; Faccenna et al., 2013). This transition corresponds to the first to second subsidence stage shift of the southern Galilee basins (Fig. 12). The DSF cuts through all previous structures along its $\sim 1000 \mathrm{~km}$ trajectory. These include the Irbid rift. As a result, the southern Galilee basins, isolated from their original system, continued to extend along an orientation tangential to the new stresses. This extension appears as the second stage of subsidence of the southern Galilee basins (Fig. 12).

Previous studies widely agree on a N-S extension of the Galilee during the upper Miocene. Schulman (1962) and Horowitz (1979) suggest that the Galilee basins continued to extend during the late Miocene. Freund (1970) calculated the finite $\mathrm{N}-\mathrm{S}$ extension based on exposed faults in the Galilee. His results indicate an increase from $0 \%$ along the Mediterranean coast, to $5 \%$ across the central Galilee, and $7 \%$ in B7 (Bet She'an basin) near the DSF. This distribution pattern of displacement also corresponds to the exposure of the Lower Basalt Fm. that decreases westwards. Freund (1970) related the differential N-S extension to the displacement along the nearby DSF. Ron and Eyal (1985) suggest that during the Miocene to early Pliocene a N-S extension with E-W compression prevailed across the Galilee. These stresses resulted in lateral shear along conjugate faults, accompanied by block rotation. The NNE-trending extensional basins defined in our results are in line with these deductions. The separation between the first (17-9 Ma) and second (9-5 Ma) stages suggested here for the first time explains the structural relations between the declining Irbid rift and the emergence of DSF dominance. The NE extension of the Galilee during the declining rifting decreases in the second stage and shifts to the NNE. However, NNE extension, including an E-W compression component, prevails into the Pliocene (Figs. 12 and 13). Plio-Pleistocene geodynamic analysis poses the study area as a seismogenic branch off the DSF plate boundary. The primary deformation zone (PDZ) is expressed by a northwest-oriented crosscutting shear that overcomes basin subsidence. Earthquake epicenter distribution and mechanisms, GPS measurements, and regional studies point to a seismogenic zone located at 9-17 km beneath the surface (Eyal and Reches, 1983; Ron and Eyal, 1985; Ben-Avraham and Ginzburg, 1990; Eyal, 1996; Hofstetter et al., 1996; Hardy et al., 2010; Salamon et al., 1996; Gomez et al., 2007; Shamir, 2007; Marco, 2007; Sadeh et al., 2012; Palano et al., 2013). Our tectonic analysis of the Galilean sheared margins in the frame of the Dead Sea fault localization process will be published in a separate paper (Wald, 2016).

\subsection{Failed rifts and magmatism}

The low extension rate $(<7 \%)$ in the Galilee corresponds to similar values in other failed rifts, such as Lake Tanganyika (Morley et al., 1990; Rosendahl, 1987). The extension is also associated with dike emplacement. Dikes may focus the strain to detachment faults (Rosenbaum et al., 2008). In Afar and Ethiopia (eastern Africa) normal faults developed during the initial stages of rifting and were abandoned $10 \mathrm{Myr}$ later. Extensional stresses there have focused on a narrow region that contains faults and magmatic intrusions (Ebinger and Casey, 2001). In the Gulf of Aden, magmatic activity was smaller. D'Acremont et al. (2005) show an abandonment of older detachment faults within the rift environment replaced by the formation of a newer, shorter segmentation along the central axis of the rift. Rift-associated magmatism therefore commences in regions distant from the rift axis and is dependent on fault distribution. In systems where extension is localized to narrow zones, dikes may follow extension lineaments. Examples of such cases are the Gulf of California (Lizarralde et al., 2007) and along the magmatic boundary of the North Atlantic (White et al., 2008). In both areas, the basaltic intrusions appear within the narrow $50-100 \mathrm{~km}$ outline of the rift. Hence, evidence for magmatic intrusions and their spatial arrangement may hint at rifting orientation and associated extensional stresses.

During the first stage of subsidence in the Galilee volcanism arrived mainly through extensional lineaments associated with normal faulting, along with the subsidence of the basins (Fig. 12). Syn-tectonic volcanism supplied the thick sections of the Lower Basalt and Hordos Fm. in B4, B6, and B7 (Figs. 6, 9, and 10b). A volcano in the southern margin of B6 and possible sources along $\mathrm{H} 2$ supplied additional volcanics that accumulated in B2, B4, and B5. The magmatic intrusions in H3 (Givat Hamore: location: Figs. 3, 10, and 7) were dated to $15 \mathrm{Ma}$ and associated with a NW to WNW faulting system (Fig. 7; Dicker, 1964; Shaliv, 1991).

Volcanism continued during the second stage of subsidence, along with the vertical and horizontal displacement of the study area. The Intermediate Basalt Fm. dated to $\sim 6 \mathrm{Ma}$ arrives through normal faults bounding $\mathrm{H} 3$ from the NE and perhaps through a volcano located in the Rewaya block (Shaliv, 1991; Fig. S8). The directional correlation between faulting and volcanic centers and lineaments (Figs. 7, 10, and 12) obeys a similar regional tendency. Equivalent correlation appears in Karak graben (Bender, 1974), Miocene dikes across Sinai (Bartov et al., 1980; Baldridge et al., 1991), and across the Harrat Ash Shaam volcanic field (Feraud et al., 1985; Mor, 1986; Giannérini et al., 1988; Brew et al., 2001; Al Kwatli et al., 2012). The strips of alkaline volcanism across the Arabian Plate represent the beginning of Miocene volcanism (Camp and Roobol, 1992; Weinstein, 2000; Ilani et al., 2001). We therefore suggest that the faulting and volcanism of the southern Galilee also follow weak lineaments in the lithosphere. 


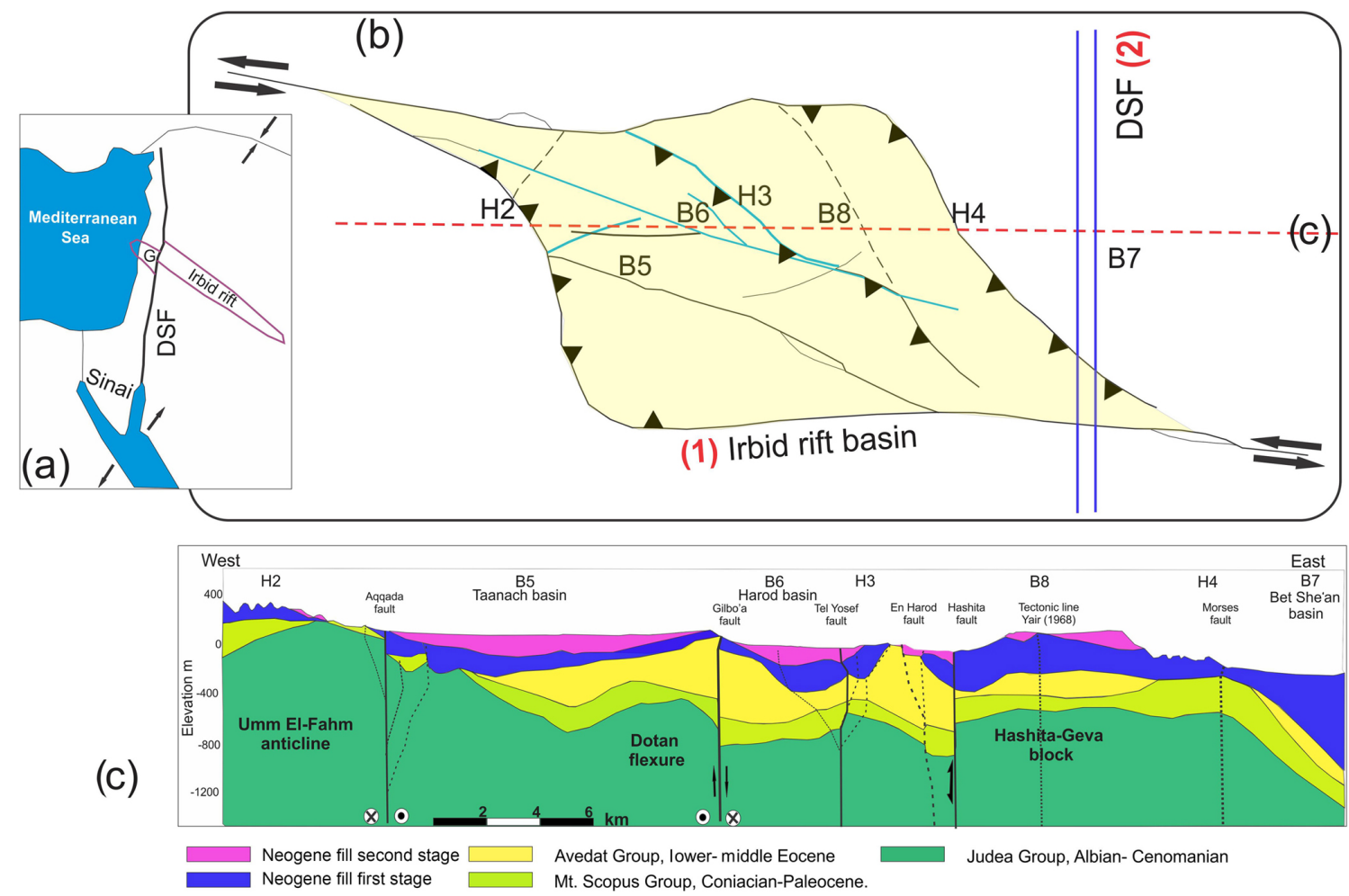

Figure 13. (a) Current plan view of the northwest-trending Irbid rift dissected by the Dead Sea fault plate boundary. (b) Neogene basin subsidence across the Galilee during the Irbid rifting (marked as first stage). NNE elongation provoked extension across the interpreted normal faults (marked by celeste lines). The second stage reflects the Dead Sea fault (DSF) stress regime, during which subsidence, normal faulting, and graben formation decrease, while complex strike-slip faulting characterizes the strain style. An establishment of a left-lateral strike-slip primary deformation zone - PDZ; modified after McClay and Bonora (2001). (c) East-west geological cross section through basins B5, B6, B8, and B7 (location: Figs. 3 and 13b). The profile is extracted from a structural model constructed for the entire study area based on seismic data, wells, and outcrops. Blue and pink shading represent the first and second subsidence stages, respectively. An inverted relief of tilted blocks is a result of a Pliocene-Pleistocene ESE compressional stress component of the Dead Sea fault stress regime. Dotted lines: less verified fault planes.

The timing of regional volcanism is noteworthy. Between 18 and $12 \mathrm{Ma}$ volcanic activity ceased across the Arabian Plate and was dominant across the southern Galilee basins (Lower Basalt Fm.). This shift may represent a NW propagation of extension and volcanism across the Arabian Plate (Weinstein, 2000). The northwestern Arabia volcanism was renewed at 14-12 Ma (Bohannon et al., 1989; Camp and Robool, 1992; Ilani et al., 2001; Krienitz et al., 2009). Several studies link the renewal and activity with structural aspects (Bayer et al., 1988; Camp and Roobol, 1992; Ebinger and Casey, 2001). However, other studies suggest that the lateral slip along the DSF decreased during the upper Miocene (Hempton, 1987; Bayer et al., 1989; Reilinger and McClusky, 2011; Faccenna et al., 2013), while drift across the NW-trending Irbid rift was active (Segev et al., 2014, 2017). Our results suggest that this decrease also enabled the subsidence of the southern Galilee basins during the second stage as part of the hybrid Red Sea-Dead Sea stress regime. With enhancement of motion along the DSF during the early Pliocene around $5 \mathrm{Ma}$, the Dead Sea stress regime became dominant, laterally shifting the southern Galilee basins and structurally isolating them from their first association with the Irbid rift.

\section{Conclusions}

The Galilee basins subsided along the northwestern front of the Irbid rift. Integration of geological and geophysical data bounds the subsidence of the basins between two major surfaces: the Oligocene regional truncation surface (RTS) and the top of the Bira Fm. unconformity. The subsidence is divided into two stages.

During the first stage (20-9 Ma) the Galilee basins subside along the main trend of the Oligo-Miocene Irbid rift system. They subside as grabens and half-grabens bounded by normal faults and structural saddles. Larger subsidence was recorded along the main NW-trending rift axis. Smaller basins subsided off the main axis. The subsidence occurred along with extensive volcanism that arrived through fault 
planes that bound the basins. The spatial arrangement of the rift basins suggests that they follow a larger principal displacement zone (PDZ). The major boundary faults mapped here are the surface expression of the PDZ strands that bound the basin complex of the rift from north and south. The complex originally formed as a releasing jog along a rift system. The structural change around $9 \mathrm{Ma}$ is associated here with the gradual transition between the Red Sea and the Dead Sea stress regimes. With the initiation of shearing along the DSF, the jog and its basins were truncated. The transition elongated the basins, accentuated their subsidence, and uplifted their surrounding margins.

During the second stage (9-5 Ma) left-lateral shearing of the entire study area results in the subsidence of a series of NNE-trending basins perpendicular to the major axis of basins from the first stage. Structural highs (i.e., blocks) that divide the first-stage basins remained high during the second stage. However, during the second stage, their bounding normal faults also exhibit a lateral component. The shear distorts the original structure of the first-stage basins north and south of the major NW-trending axis in such a way that today these periphery early Neogene basins have been uplifted and weathered. The length of the basins decreases from $\sim 60 \mathrm{~km}$ in the east to $\sim 15 \mathrm{~km}$ in the west of the study area. The volcanism of the second stage arrives from weak zones and focuses on structural boundaries between the basins and volcanic activity along their margins.

The structural architecture of the southern Galilee indicates that the rift basins continued to subside while the Irbid rift was active. Their shape and arrangement were constrained by two main rheological features - the bounds of a releasing jog along the PDZ (i.e., Carmel-Gilboa fault line) and the acquaintance with a more cohesive crust at the peripheral area, perhaps a "locked zone" (see Lyakhovsky et al., 2012; Segev et al., 2014). Locked zones involve preexisting discontinuities such as transitions between oceanic and continental crust types or perpendicular faulting arrays (Courtillot et al., 1987; Dunbar and Sawyer, 1996). However, following the numerical modeling results, neither of these seems to have caused the cessation of rifting. In fact, the basins at the rift tip subsided until the jog was decapitated by the motion along the DSF. Following the two-staged subsidence model of the Oligo-Miocene, the main cause of the structural transition (and preservation) of the southern Galilee basins was the transition from one dominant stress regime to another. Our study provides a unique and detailed architecture of a rift termination basin complex. Based on this case study we suggest that the rift front did not fail but rather faded and was taken over by a more dominant stress regime. Otherwise, basins of this failing rift front could have simply died out.

Data availability. Datasets processed herein are owned by governmental archives. We provide our processed datasets in the Supplement.
Supplement. The supplement related to this article is available online at: https://doi.org/10.5194/se-10-225-2019-supplement.

Author contributions. This work is based on a profound chapter from RW's $\mathrm{PhD}$ thesis. RW has processed and analyzed the datasets, including seismic interpretation and development of a 3-D geological model. AS, ZB-A, and US have critically read and reviewed all the data following their participation in the work as thesis advisors. US has contributed to writing and figure graphics. RW has prepared the paper with major contributions from US and with the review of all coauthors.

Competing interests. The authors declare that they have no conflict of interest.

Special issue statement. This article is part of the special issue "Advances in seismic imaging across the scales". It is not associated with a conference.

Acknowledgements. We thank both the Israel Geological Survey (Jerusalem) and the Graduate Studies Authority of the University of Haifa for funding this research. We are grateful to John Hall, Anat Kedem, and Devrim Tezcan for their help in processing seismic datasets. We thank the Kingdom Suite and Schlumberger-Petrel for providing academic licenses that facilitated this study. The Kingdom Suite software has been used for archiving and editing the data, whereas Schlumberger-Petrel has been used for 3-D modeling and geologic 2-D slice presentations. This paper highly benefited from the productive reviews of Piotr Krzywiec and an anonymous reviewer.

Edited by: Michal Malinowski

Reviewed by: Piotr Krzywiec and one anonymous referee

\section{References}

Abelson, M., Sneh, A., Rosensaft, M., Borshevsky, A., Shaliv, G., and Wollman, S.: Reconstruction of the rock layers in the Galilee - Early Cretaceous to present - for the Kalanit project, Israel Geological Survey Report GSI/28/2009, Jerusalem, 12 pp., 2009 (in Hebrew).

Agar, R. A.: The Najd fault system revisited; a two-way strike-slip orogen in the Saudi Arabian Shield, J. of Struct. Geol., 9, 41-48, https://doi.org/10.1016/0191-8141(87)90042-3, 1987.

Aizenberg, E.: Report on the Sarid 1 and Gid'on Structure Holes in Emek Yizre'el, Naphta Israel Petroleum Corp., Tel-Aviv, Israel, 1967.

Allen, P. A. and Allen, J. R. (Eds.): Basin Analysis - Principles and Applications, 2nd Edition, Blackwell Publishing, Oxford, UK, 2005.

Al Kwatli, M. A., Gillot, P. Y., Zeyen, H., Hildenbrand, A., and Al Gharib, I.: Volcano-tectonic evolution of the northern part of the Arabian plate in the light of new $\mathrm{K}-\mathrm{Ar}$ ages and remote sensing: 
Harrat Ash Shaam volcanic province (Syria), Tectonophysics, 580, 192-207, https://doi.org/10.1016/j.tecto.2012.09.017, 2012. ArRajehi, A., McClusky, S. Reilinger, R. Daoud, M., Alchalbi, A., Ergintav, S., Gomez, F., Sholan, J., Bou-Rabee, F., Ogubazghi, G., Haileab, B., Fisseha, S., Asfaw, L., Mahmoud, S., Rayan, A., Bendik, R., and Kogan L.: Geodetic constraints on present-day motion of the Arabian Plate: Implications for Red Sea and Gulf of Aden rifting, Tectonics, 29, TC3011, https://doi.org/10.1029/2009TC002482, 2010.

Avni, Y.: The geology, paleogeography and landscape evolution in the central Negev highlands and the western Ramon structure, Israel Geological Survey Report GSI/6/91, Jerusalem, 153 pp., 1991 (in Hebrew with English abstract).

Avni, Y.: The structural and landscape evolution of the western Ramon structure, Israel J. Earth Sci., 42, 177-187, 1993.

Avni, Y.: Paleogeography and tectonics of the central Negev and the Dead Sea rift western margin during the Late Neogene and Quaternary, Ph.D. Thesis, the Hebrew University, Jerusalem, and the Israel Geological Survey Report GSI/24/98, Jerusalem, Israel, 231 pp., 1998 (in Hebrew with English abstract).

Avni, Y., Segev, A., and Ginat, H: Oligocene regional denudation of the northern Afar dome: pre and syn-breakup stages of the Afro-Arabian plate, Geol. Soc. Am. Bull., 124, 1871-1897, https://doi.org/10.1130/B30634.1, 2012.

Baer, G., Aharon, L., Heimann, A., Shaliv, G., and Agnon, A.: The Nahal Tavor vent: interplay of Miocene tectonics, dikes and volcanism in the Lower Galilee, Israel J. Earth Sci., 55, 1-16, 2006.

Baldridge, W. S., Eyal, Y., Bartov, Y., and Steinitz, G., and Eyal, M.: Miocene magmatism of Sinai related to the opening of the Red Sea, Tectonophysics, 197, 181-201, 1991.

Bar, O., Gvirtzman, Z., Feinstein, S., and Zilberman, E.: Accelerated subsidence and sedimentation in the Levant basin during the Late Tertiary and concurrent uplift of the Arabian platform: Tectonic versus counteracting sedimentary loading effects, Tectonics, 32, 334-350, 2013.

Bar, O., Zilberman, E., Feinstein, S., Calvo, R., and Gvirtzman, Z.: The uplift history of the Arabian Plateau as inferred from geomorphologic analysis of its northwestern edge, Tectonophysics, 671, 9-23, 2016.

Bartov, Y., Steinitz, G., Eyal, M., and Eyal, Y.: Sinistral movement along the Gulf of Aqaba - Its age and relation to the opening of the Red Sea, Nature, 285, 220-222, https://doi.org/10.1038/285220a0, 1980.

Bartov, Y., Sneh, A., Fleischer, L. Arad, V., and Rosensaft, M.: Potentially active faults in Israel - stage B, Israel Geological Survey Report GSI/29/2002, 8 pp., 2002 (in Hebrew).

Bayer, H. J., Hötzl, H., Jado, A. R., Roscher, B., and Voggenreiter, W.: Sedimentary and structural evolution of the northwest Arabian Red Sea margin, Tectonophysics, 153, 137-151, 1988.

Bayer, H. J., Hötzl, H., El-Isa, Z., Mechie, J., Prodehl, C., and Saffarini, G.: Large tectonic and lithospheric structures of the Red Sea region, J. Afr. Earth Sci., 8, 565-587, 1989.

Beauchamp, W., Barazangi, M., Demnati, A., and El Alji, M.: Intracontinental Rifting and Inversion: Missour Basin and Atlas Mountains, Morocco, Am. Assoc. Petr. Geol. B., 80, 1459-1482, 1996.

Beauchamp, W., Allmending, R. W., Barazangi, M., Demnati, A., El Alji, M., and Dahmani, M.: Inversion tectonics and the evolution of the High Atlas Mountains, Morocco, based on a geologicalgeophysical transect, Tectonics, 18, 163-184, 1999.

Bellahsen, N., Faccenna, C., Funiciello, F., Daniel, J. M., and Jolivet, L.: Why did Arabia separate from Africa? Insights from 3D laboratory experiments, Earth Planet. Sc. Lett., 216, 365-381, 2003.

Ben-Avraham, Z. and Ginzburg, A.: Displaced terranes and crustal evolution of the Levant and the eastern Mediterranean, Tectonics, 9, 613-622, 1990.

Ben David, R.: Stages in the evolution of landscape in the Makhtesh Ramon and Nahal Neqarot area- Field excursion, Israel J. Earth Sci., 42, 189-196, 1993.

Ben David, R. and Mazor, E.: Stages in the evolution of Makhtesh Ramon and it drainage system, Israel J. Earth Sci., 37, 125-135, 1988.

Bender, F.: Geology of Jordan, Berlin, Gebrüder Borntraeger, 196 pp., 1974.

Bentor, Y. K.: The crustal evolution of the Arabo-Nubian Massif with special reference to the Sinai Peninsula, Precambrian Res., 28, 1-74, 1985.

Blake, G. S.: On the occurrence of marine Miocene in Palestine, Geol. Mag., 72, 140-142, 1935.

Bohannon, R. G., Naesar, C. W., Schmidt, D. L., and Zimmerman, R. A.: The timing of uplift, volcanism and rifting peripheral to the Red Sea: A case for passive rifting?, J. Geophys. Res., 94, 1683-1701, 1989.

Bosworth, W.: Discussion on the structural evolution of extensional basin margins, J. Geol. Soc. London, 142, 939-942, 1985.

Bosworth, W.: A model for the three-dimensional evolution of continental basins, north-east Africa, Geol. Rundsch., 83, 671-688, 1994.

Bosworth, W., Lambiase, J., and Keisler, R.: A new look at Gregory's Rift: The structural style of continental rifting, EOS, AGU Transact., 67, 577-583, 1986.

Bosworth, W., Huchon, P., and McClay, K.: The Red Sea and Gulf of Aden Basins, J. Afr. Earth Sci., 43, 334-378, https://doi.org/10.1016/j.jafrearsci.2005.07.020, 2005.

Brew, G., Lupa, J., Barazangi, M., Sawaf, T., Al-Imam, A., and Zaza, T.: Structure and tectonic development of the Ghab Basin and the Dead Sea fault system, Syria, J. Geol. Soc. London, 158, 665-674, 2001.

Brueseke, M. E., Hobbs, J. M., Bulen, C. L., Mertzman, S. A., Puckett, R. E., Walker, J. D., and Feldman, J.: Cambrian intermediate-mafic magmatism along the Laurentian margin; evidence for flood basalt volcanism from well cuttings in the Southern Oklahoma Aulacogen (U.S.A.), Lithos, 260, 164-177, https://doi.org/10.1016/j.lithos.2016.05.016, 2016.

Burgess, C. F., Rosendahl B. R., Sander S., Burgess C. A., Lambiase J., Derksen S., and Meader N.: The structural and stratigraphic evolution of Lake Tanganyika: a case history in continental rifting, in: Rifting and the Opening of the Atlantic Ocean, edited by: Manspeizer, W., Elsevier, Amsterdam, 861-881, 1988.

Busby, C. J. and Ingersoll, R. V.: Tectonics of Sedimentary Basins, Blackwell Science, Oxford, UK, 579 pp., 1995.

Camp, V. E. and Roobol, M. J.: Upwelling asthenosphere beneath Western Arabia and its regional implications, J. Geophys. Res., 97, 15255-15271, https://doi.org/10.1029/92JB00943, 1992.

Chang, S. J., Merino, M., Van Der Lee, S., Stein, S., and C. A., Stein: Mantle flow beneath Arabia offset from 
the opening Red Sea, Geophys. Res. Lett., 38, L04301, https://doi.org/10.1029/2010GL045852, 2011.

Courtillot, V., Armijo, R., and Tapponnier P.: The Sinai triple junction revisited, Tectonophysics, 141, 181-190, https://doi.org/10.1016/0040-1951(87)90184-3, 1987.

d'Acremont, E., Leroy, S., Beslier, M. O., Bellahsen, N., Fournier, M., Robin, C., Maia, M., and Gente, P.: Structure and evolution of the eastern Gulf of Aden conjugate margins from seismic reflection data, Geophys. J. Int., 160, 869-890, https://doi.org/10.1111/j.1365-246X.2005.02524.x, 2005.

de Castro, D. L. and Bezerra, F. H. R.: Fault evolution in the Potiguar rift termination, equatorial margin of Brazil, Solid Earth, 6, 185-196, https://doi.org/10.5194/se-6-185-2015, 2015.

Dekel, A.: Geology of Emek-Dotan area, MSc. Thesis, Tel-Aviv University, Tel-Aviv, Israel, 62 pp., 1988 (in Hebrew).

Dembo, N., Hamiel, Y., and Granot, R.: Intraplate rotational deformation induced by faults: Carmel-Gilboa fault system as a case study, Israel Geological Survey Report GSI/19/2015, 32 pp., 2015.

De Vicente, G. and Muñoz-Martin, A.: The Madrid Basin and the Central System: A tectonostratigraphic analysis from 2-D seismic lines, Tectonophysics, 602, 259-285, https://doi.org/10.1016/j.tecto.2012.04.003, 2013.

Dézes, P., Schmid, S. M., and Ziegler, P. A.: Evolution of the European Cenozoic Rift System: interaction of the Alpine and Pyrenean orogens with their foreland lithosphere, Tectonophysics, 389, 1-33, https://doi.org/10.1016/j.tecto.2004.06.011, 2004.

Dicker, T.: The Geology of central Yizre'el Valley, MSc. Thesis, the Hebrew University, Jerusalem, Israel, 1964.

Dicker, T.: The Geology of central Yizre'el Valley, Israel J. Earth Sci., 18, 39-69, 1969.

Dunbar, J. A. and Sawyer, D. S.: Three-dimensional dynamical model of continental rift propagation and margin plateau formation, J. Geophys. Res., 101, 27845-27863, 1996.

Ebinger, C. J. and Casey, M.: Continental breakup in magmatic provinces: an Ethiopian example, Geology, 29, 527-530, 2001.

Ebinger, C. J., Rosendahl, B. R., and Reynolds, D. J.: Tectonic model of the Malawi Rift, Africa, Tectonophysics, 141, 215-235, 1987.

Ebinger, C. J., Deino, A. L., Drake, R. E., and Tesha, A. L.: Chronology of volcanism and rift basin propagation: Rungwe volcanic province, East Africa, J. Geophys. Res., 94, 1578515803, 1989.

Enachescu, M.: Structural setting and petroleum potential of the Orphan basin, offshore Newfoundland and Labrador, Canadian Society of Exploration Geophysicists Recorder, 31, 5-13, 2006.

Evison, F. F.: On the growth of continents by plastic flow under gravity, Geophys. J. Roy. Astr. S., 3, 155-190, 1959.

Eyal, Y.: Stress field fluctuations along the Dead Sea rift since the middle Miocene, Tectonics, 15, 157-170, 1996.

Eyal, Y. and Reches, Z.: Tectonic analysis of the Dead Sea rift region since the Late Cretaceous based on mesostructures, Tectonics, 2, 167-185, 1983.

Eyal, Y., Gross, M. R., Engelder, T., and Becker, A.: Joint development during fluctuation of regional stress field in southern Israel, J. Struct. Geol., 23, 279-296, 2001.

Faccenna, C., Becker, T. W., Jolivet, L., and Keskin, M.: Mantle convection in the Middle East: Reconciling Afar upwelling, Arabia indentation and Aegean trench rollback, Earth Planet. Sc.
Lett., 375, 254-269, https://doi.org/10.1016/j.epsl.2013.05.043, 2013.

Feraud, G., Giannerini, G., and Campredon, R.: Dyke Swarms as Paleostress Indicators in Areas Adjacent to Continental Collision Zones: Examples from the European and Northwest Arabian Plates, Mafic Dyke Swarms, International Lithosphere Program, Erindale College, University of Toronto, Ontario, Canada, 273278, 1985.

Freund, R.: Geometry of faulting in Galilee, Israel J. Earth Sci., 19, 117-140, 1970.

Freund, R.: The concept of a sinistral megashear, in: Lake Kinneret, edited by: Serruya, C., Monographiae biologicae, 32, Dr. W. Junk B. V. Publishers, The Hague, the Netherlands, 27-31, 1978.

Frieslander, U.: Seismic interpretation of the Revaya region (Bet She'an valley), Geophysical Institute of Israel, Lod, Report 648/25/97, 1997 (in Hebrew).

Frizon de Lamotte, D., Raulin, C., Mouchot, N., Wrobel-Daveau, J.C., Blanpied, C., and Ringenbach, J.-C.: The southernmost margin of the Tethys realm during the Mesozoic and Cenozoic: Initial geometry and timing of the inversion processes, Tectonics, 30, TC3002, https://doi.org/10.1029/2010TC002691, 2011.

Gardosh, M. and Bruner, I.: Seismic survey in Bet She' an region, Geophysical Institute of Israel Report 348/27/98, Lod, 1998 (in Hebrew).

Gardosh, M., Druckman, Y., Buchbinder, B., and Rybakov, M.: The Levant Basin offshore Israel: stratigraphy, structure, tectonic evolution and implications for hydrocarbon exploration - revised edition, Geophysical Institute of Israel Report 429/328/08, Lod, Israel Geological Survey Report GSI/4/2008, Jerusalem, Israel, 118 pp., 2008.

Garfunkel, Z.: The tectonics of the western margins of the southern Arava, a contribution to the understanding of rifting, Ph.D. Thesis, the Hebrew University of Jerusalem, Jerusalem, Israel, 203 pp., 1970 (in Hebrew with English abstract).

Garfunkel, Z.: Internal structure of the dead-sea leaky transform (rift) in relation to plate kinematics, Tectonophysics, 80, 81-108, 1981.

Garfunkel, Z.: Dead Sea leaky transform (rift) in relation to plate kinematics, Tectonophysics, 80, 81-108, 1989.

Garfunkel, Z.: Constrains on the origin and history of the Eastern Mediterranean basin, Tectonophysics, 298, 5-35, 1998.

Garfunkel, Z.: Early Palaeozoic sediments of NE Africa and Arabia, Products of continental-scale erosion, sediment transport, and deposition, Israel J. Earth Sci., 51, 135-156, 2002.

Garfunkel, Z.: Origin of the Eastern Mediterranean basin: a reevaluation, Tectonophysics, 391, 11-34, 2004.

Garfunkel, Z. and Bartov, Y.: The tectonics of the Suez rift, Israel Geologic Survey Bulletin, 71, 1-44, 1977.

Garfunkel, Z. and Ben-Avraham, Z.: Basins along the Dead Sea Transform, Peri-tethyan Rift/Wrench Basins and Passive Margins, in: Peri-tethys Memoir 6, edited by: Ziegler, P. A., Cavazza, W., Robertson, A. H. F., and Crasquin-Soleau, S., Museum National d'Histoire Naturelle, Paris, 607-627, 2001.

Garfunkel, Z. and Derin, B.: Permian-early Mesozoic tectonism and continental margin formation in Israel and its implications for the history of the Eastern Mediterranean, in: The Geological Evolution of the Eastern Mediterranean, edited by: Dixon, R. J. and Robertson, A. H. F., Geol. Soc. London Spec. Pub., 17, 187-201, 1984. 
Garfunkel, Z. and Horowitz, A.: The Upper Tertiary and Quaternary morphology of the Negev, Israel, Israel J. Earth Sci., 15, 101$117,1966$.

Gev, I.: Salinization phenomena of the soils in Yizrael Valley as a result of the hydrogeological System, MSc Thesis, Ben-Gurion University in the Negev, Beer Sheva, Israel, 149 pp., 1989 (in Hebrew with English abstract).

Giannérini, G., Campredon, R., Féraud, G., and Abou, Z. B.: Déformations intraplaques et volcanisme associé; exemple de la bordure NW de la plaque Arabique au Cénozoïque (Intraplate deformation and associated volcanism; example of the northwestern edge of the Arabian Plate during the Cenozoic), B. Soc. Geol. Fr., 4, 937-947, 1988.

Ginzburg, A., Ben-Avraham, Z., Makris, J., Hubral, P., and Rotstein, Y.: Crustal structure of northern Israel, Mar. Petrol. Geol., 11, 501-506, 1994.

Gomez, F., Khawlie, M., Tabet, C., Darkal, A., Khair, K., and Barazangi, M.: Late Cenozoic uplift along the northern Dead Sea transform in Lebanon and Syria, Earth Planet. Sc. Lett., 241, 913-931, 2006.

Gomez, F., Karam, G., Khawlie, M., McClusky, S., Vernant, P., Reilinger, R., Jaafar, R., Tabet, C., Khair, K., and Barazangi, M.: Global Positioning System measurements of strain accumulation and slip transfer through the restraining bend along the Dead Sea fault system in Lebanon, Geophys. J. Int., 168, 1021-1028, https://doi.org/10.1111/j.1365-246X.2006.03328.x, 2007.

Guiraud, R. and Bosworth, W.: Senonian basin inversion and rejuvenation of rifting in Africa and Arabia: synthesis and implications to plate-scale tectonics, Tectonophysics, 282, 39-82, 1997.

Gvirtzman, Z., Steinberg, J., Bar, O., Buchbinder, B., Zilberman, E., Siman-Tov, R., Calvo, R. Grossowicz, L. Almogi-Labin, A., and Rosensaft, M.: Retreating Late Tertiary shorelines in Israel: Implications for the exposure of north Arabia and Levant during Neotethys closure, Lithosphere, 3, 95-109, 2011.

Haq, B. U., Hardenbol, J., and Vail, P. R.: Chronology of sea-level fluctuations since the Triassic, Science, 235, 1156-1167, 1987.

Hansen, S. E. and Nyblade, A. A.: The deep seismic structure of the Ethiopia/Afar hotspot and the African superplume, Geophys. J. Int., 194, 118-124, https://doi.org/10.1093/gji/ggt116, 2013.

Hardy, C., Homberg, C., Eyal, Y., Barrier, E., and Müller, C.: Tectonic evolution of the southern Levant margin since Mesozoic, Tectonophysics, 494, 211-225, 2010.

Hatzor, Y.: The Geology of Mt. Gilboa, Israel Geological Survey Report GSI/15/91, Jerusalem, Israel, 107 pp., 1988 (in Hebrew with English abstract)

Heimann, A., Steinitz, G., Mor, D., and Shaliv G.: The geochronology of the Cover Basalt: revised K-Ar and new 40-Ar/39-Ar results?, Geological Survey of Israel Report GSI/6/96, 35 pp., 1996.

Hempton, M. R.: Constraints on Arabian plate motion and extensional history of the Red Sea, Tectonics, 6, 687-705, 1987.

Hensen, F. R. S.: Observations on the geology of the petroleum occurrences of the Middle East, Proceedings of 3rd World Petroleum Congress, The Hague, the Netherlands, World Petroleum Congress, Volume 1, 118-140, 1951.

Hoffman, P., Dewey, J. F., and Burke, K.: Aulacogens and their genetic relation to geosynclines, with a Proterozoic example from Great Slave lake, Canada, in: Modern and ancient geosynclinal sedimentation, edited by: Dott Jr., R.H. and Shaver, R. H.:, Soc. Econ. Pa, 19, 38-55, 1974.

Hofmann, C. and Courtillot, V.: Timing of the Ethiopian food basalt event and implications for plume birth and global change, Nature, 389, 838-841, 1997.

Hofstetter, A., van Eck, T., and Shapira, A.: Seismic activity along the fault branches of the Dead Sea - Jordan transform: the Carmel-Tirtza fault system, Tectonophysics, 267, 317-330, 1996.

Horowitz, A.: The Quaternary of Israel, Academic Press, New York, 394 pp., 1979.

Horowitz, A.: Palynology of Arid Lands, Elsevier, Amsterdam, Netherlands, 546 pp., 1992.

Horowitz, A.: The Jordan Rift Valley, AA. Balkema publishers, Rotterdam, Netherlands, 730 pp., 2001.

Hurwitz, S., Garfunkel, Z., Ben-Gai, Y., Reznikov, M., Rotstein, Y., and Gvirtzman, H.: The tectonic framework of a complex pullapart basin: seismic reflection observations in the Sea of Galilee, Dead Sea transform, Tectonophysics, 359, 289-306, 2002.

Ilani, S., Harlavan, Y., Tarawneh, K., Rabba, I., Weinberger, R., Ibrahim, K., Peltz, S., and Steinitz, G.: New K-Ar ages of basalts from the Harrat Ash Shaam volcanic field in Jordan: implications for the span and duration of the upper-mantle upwelling beneath the western Arabian plate, Geology, 29, 171-174, 2001.

Inbar, N.: The evaporitic subsurface body of Kinnarot basin stratigraphy, structure, geohydrology, $\mathrm{PhD}$ thesis, Tel-Aviv University, Tel-Aviv, 131 pp., 2012.

Joffe, S. and Garfunkel, Z.: Plate kinematics of the circum Red Sea - a re-evaluation, Tectonophysics, 153, 271-294, 1987.

Kafri, U.: Neogene to Early Quaternary drainage systems in the Lower Galilee, Israel and their relationship to young tectonics, Israel J. Earth Sci., 51, 79-102, https://doi.org/10.1560/WH4Y3NNT-TQ2W-1D9D, 2002.

Kafri, U. and Ecker, A.: Neogene and Quaternary subsurface geology and hydrogeology of the Zevulun plain, Israel Geological Survey Bulletin, 37, 13 pp., 1964.

Khalil, S. M. and McClay, K. R.: Extensional fault-related folding, northwestern Red Sea Egypt, J. of Struct. Geol. 24, 743-762, https://doi.org/10.1016/s0191-8141(01)00118-3, 2002.

Khalil, S. M. and McClay, K. R.: 3D geometry and kinematic evolution of extensional fault-related folds, NW Red Sea, Egypt, in: The geometry and growth of normal faults, edited by: Childs, C., Holdsworth, R. E., Jackson, C. A. L., Manzocchi, T., Walsh, J. J., and Yielding, G., Geol. Soc. London, Spec. Pub., 439, 109-130, https://doi.org/10.1144/SP439.11, 2017.

Klang, A. and Sherman, J.: Emeq Yizreel Area Seismic Reflection Survey, The Institute for Petroleum Research and Geophysics of Israel, Report S.I.809-3/70, 6 pp., 1972.

Krenkel, E.: Der Syrische Bogen, Zentralblatt Mineralogie, 9, 274 281, 1924.

Krienitz, M. S., Haase, K. M., Mezger, K., van den Bogaard, P., Thiemann, V., and Shaikh- Mashail, M. A.: Tectonic events, continental intraplate volcanism, and mantle plume activity in northern Arabia: constraints from geochemistry and Ar-Ar dating of Syrian lavas, Geochem. Geophy. Geosy., 10, Q04008, https://doi.org/10.1029/2008GC002254, 2009.

Krijgsman, W., Hilgen, F. J., Raffi, I., Sierro, F. J., and Wilson, D. S.: Chronology, causes and progression of the Messinian salinity crisis, Nature, 400, 652-655, 1999. 
Lesti, C., Giordano, G., Salvini, F., and Cas, R.: Volcano tectonic setting of the intraplate, Pliocene-Holocene, Newer Volcanic Province (southeast Australia): Role of crustal fracture zones, J. Geophys. Res., 113, B07407, https://doi.org/10.1029/2007JB005110, 2008.

Letouzey, J. and Tremolieres, P.: Paleostress around the Mediterranean since the Mesozoic from microtectonics: comparison with Plate tectonic data, Rock Mech., 8, 173-192, 1980.

Lizarralde, D., Axen, G. J., Brown, H. E., Fletcher, J. M., GonzalesFernandez, A., Harding, A. J., Holbrook, W. S., Kent, G. M., Paramo, P., Sutherland, F., and Umhoefer, P. J.: Variation in styles of rifting in the Gulf of California, Nature, 448, 466-469, https://doi.org/10.1038/nature06035, 2007.

Lyakhovsky, V., Segev, A., Schattner, U., and Weinberger, R.: Deformation and seismicity associated with continental rift zones propagating toward continental margins, Geochem. Geophy. Geosy., 13, 1-21, https://doi.org/10.1029/2011GC003927, 2012.

Manzi, V., Gennari, R., Hilgen, F. J., Krijgsman, W., Lugli, S., Roveri, M., and Serro, F. J.: Age refinement of the Messinian salinity crisis onset in the Mediterranean, Terra Nova, 25, 315322, 2013.

Marco, S.: Temporal variation in the geometry of a strike-slip fault zone: examples from the Dead Sea transform, Tectonophysics, 445, 186-199, 2007

Matmon A., Wdowinski, S., and Hall, J. K.: Morphological and structural relations in the Galilee extensional domain, northern Israel, Tectonophysics, 371, 223-241, 2003.

May, P.: Oil and gas potential of the Galilee, Israel, Oil Exploration (Investments) Ltd Report, 87/12, 73 pp., 1987.

McClay, K. and Khalil, S. M: Extensional hard linkages, eastern Gulf of Suez, Egypt, Geology, 26, 563-566, 1998.

McClay, K. and Bonora, M.: Analog models of restraining stepovers in strike-slip fault systems, Am. Assoc. Petr. Geol. B., 85, 233 260, 2001

McQuarrie, N., Stock, J. M., Verdel, C., and Wernicke, B. P.: Cenozoic evolution of Neotethys and implications for the causes of plate motions, Geophys. Res. Lett., 30, 2036, https://doi.org/10.1029/2003GL017992, 2003.

Meiler, M., Shulman, H., Flexer, A., Reshef, M., and Yellin-Dror, A.: A seismic interpretation of the Bet She'an basin, Israel J. Earth Sci., 57, 1-19, 2008.

Melo, A., de Castro, D. L., Bezerra, F. H. R, and Bertotti, J.: Rift fault geometry and evolution in the Cretaceous Potiguar Basin (NE Brazil) based on fault growth models, J. S. Ame. Earth Sci., 71, 96-107, https://doi.org/10.1016/j.jsames.2016.07.006, 2016.

Mero, D.: Subsurface geology of western Galilee and Zevulun plain, TAHAL consulting engineers LTD., Report 04/83/48, 36 pp., 1983.

Michelson, C. and Lipson-Benitah, S.: The litho and biostratigraphy of the southern Golan Heights, Israel J. Earth Sci., 35, 221-240, 1986.

Molnar, N. E., Cruden, A. R., and Betts, P. G.: Interactions between propagating rotational rifts and linear rheological heterogeneities: Insights from threedimensional laboratory experiments, Tectonics, 36, 420-443, https://doi.org/10.1002/2016TC004447, 2017.

Mor, D.: The volcanism of the Golan Heights. Ph.D. Thesis, the Hebrew University, Jerusalem, Israel, and Israel Geological Sur- vey Report, GSI/5/86, 159 pp., 1986 (in Hebrew with English abstract).

Morley, C. K., Nelson, R. A., Patton, T. L., and Munn, S. G.: Transfer zones in the East African rift system and their relevance to hydrocarbon exploration in rifts, Am. Assoc. Petr. Geol. B., 74, 1234-1253, 1990.

Morley, C. K., Haranya, C., Phoosongsee, W., Pongwapee, S., Kornsawanc, A., and Wonganan, N.: Activation of rift oblique and rift parallel pre-existing fabrics during extension and their effect on deformation style: examples from the rifts of Thailand, J. Struct. Geol., 26, 1803-1829, 2004.

Müller, D. W. and Hsu, K. J.: Event stratigraphy and paleoceanography in the Fortuna Basin (southeast Spain): A scenario for the Messinian salinity crisis, Paleoceanography, 2, 679-696, 1987.

Nuriel, P., Weinberger, R., Kylander-Clark, A. R. C., Hacker, B. R., and Cradock, J. P.: The onset of the Dead Sea transform based on calcite age-strain analyses, Geology, 45, 587-590, https://doi.org/10.1130/G38903.1, 2017.

Oliveira, D. C. and Mohriak, W. U.: Jaibaras trough: an important element in the early tectonic evolution of the Parnaíba interior sag basin, Northern Brazil, Mar. Petrol. Geol., 20, 351-383, 2003.

Palano, M., Imprescia, P., and Gresta, S.: Current stress and strain-rate fields across the Dead Sea Fault System: Constraints from seismological data and GPS observations, Earth and Planet. Sc. Lett., 369-370, 305-316, https://doi.org/10.1016/j.epsl.2013.03.043, 2013.

Picard, L.: Structure and evolution of Palestine, with comparative notes on neighbouring countries, Hebrew University Jerusalem Geological Department Bulletin, 4, 1-143, 1943.

Picard, L.: Geomorphology of Israel: Part I, The Negev, Israel Geological Survey Bulletin, 1, 5-32, 1951.

Pik, R., Marty, B., Carignan, J., and Lave, J.: Stability of the Upper Nile drainage network (Ethiopia) deduced from (U-Th)/He thermochronometry: implications for uplift and erosion of the Afar plume dome, Earth Planet. Sc. Lett., 215, 73-88, 2003.

Politi, M.: Seismic interpretation of central Emeq Yisrael, Oil Exploration (Investments) Ltd Report 83/39, 24 pp., 1983.

Quennell, A. M.: The structural and geomorphic evolution of the Dead Sea Rift, Geol. Soc. London Spec. Pub., 114, 1-24, 1958.

Reilinger, R. and McClusky, S.: Nubia-Arabia-Eurasia plate motions and the dynamics of Mediterranean and Middle East tectonics, Geophys. J. Int., 186, 971-979, 2011.

Ritesma, J., Van Heijst, H. J., and Woodhouse, J. H.: Complex shear wave velocity structure imaged beneath Africa and Iceland, Science, 286, 1925-1928, https://doi.org/10.1126/science.286.5446.1925, 1999.

Robertson, A. H. F.: Mesozoic-Tertiary tectonic evolution of the easternmost Mediterranean area: integration of marine and land evidence, in: Proceedings Ocean Drilling Progress Scientific Results, edited by: Robertson, A. H. F., Eneis, K. C., Richter, C., and Camerlenghi, A., 160, 723-782, 1998.

Ron, H. and Eyal, Y.: Intraplate deformation by block rotation and mesostructures along the Dead Sea Transform, Northern Israel, Tectonics, 4, 85-105, 1985.

Rosenbaum, G., Weinberg, R. F., and Regenauer-Lieb, K.: The geodynamics of lithospheric extension, Tectonophysics, 458, 1-8, 2008 . 
Rosendahl, B. R.: Architecture of continental rifts with special reference to east Africa, Annu. Rev. Earth Pl. Sc., 15, 445-503, 1987.

Rosenthal, E., Weinberger, G., Almogi, A., and Flexer, A.: Late Cretaceous-Early Tertiary development of depositional basins in Samaria as a reflection of Eastern Mediterranean tectonic evolution, Am. Assoc. Petr. Geol. B., 84, 997-1014, 2000.

Rotstein, Y., Shaliv, G., and Rybakov, M.: Active tectonics of the Yizre'el valley, Israel, using high resolution seismic reflection data, Tectonophysics, 382, 31-50, 2004.

Rozenbaum, A. G., Sandler, A., Zilberman, E., Stein, M., Jicha, B. R., and Singer, B. S.: ${ }^{40} \mathrm{Ar} /{ }^{39} \mathrm{Ar}$ chronostratigraphy of late Miocene-early Pliocene continental aquatic basins in SE Galilee, Israel, Geol. Soc. Am. Bull., 128, 1383-1402, https://doi.org/10.1130/B31239.1, 2016.

Sadeh, M., Hamiel, Y., Ziv, A., Bock, Y., Fang, P., and Wdowinski, S.: Crustal deformation along the Dead Sea Transform and the Carmel Fault inferred from 12 years of GPS measurements, J. Geophys. Res., 117, B08410, https://doi.org/10.1029/2012JB009241, 2012.

Sagy, Y. and Gvirtzman, Z.: Subsurface mapping in The Zevulun Valley, Geophysical Institute of Israel Report, Lod, 648/454/09, 21 pp., 2009 (in Hebrew).

Sagy, Y., Gvirtzman, Z., and Reshef, M.: 80 m.y. of folding migration: New perspective on the Syrian arc from Levant Basin analysis, Geology, 46, 175-178, 2017.

Salamon, E., Hofstteter, A., Garfunkel, Z., and Ron, H.: Seismicity of the eastern Mediterranean region: perspective from the Sinai subplate, Tectonophysics, 263, 293-305, 1996.

Sandler, A., Harlavan, Y., and Shaliv, G.: The stratigraphy of Neogene conglomerates in the Yizre'el Valley, Israel J. Earth Sci., 53, 77-86, 2004.

Sandler A., Rozenbaum, A. G., Zilberman, E., Stein, M., Jicha, B. R., and Singer, B. S.: Updated ${ }^{40} \mathrm{Ar}^{39}{ }^{39} \mathrm{Ar}$ Chronology for Top Lower Basalt, Base Cover Basalt, and Related Units, Northern Valleys, Israel, Israel Geological Society Annual Meeting, Kinar, Israel, 2015.

Sass, E.: Geology and petrology of the Umm El Fahm area, Ph.D. Thesis, the Hebrew University of Jerusalem, Jerusalem, Israel, 174 pp., 1966 (in Hebrew with English abstract).

Schattner, U. and Lazar, M.: Flip convergence across the Phoenician basin through nucleation of subduction, Gondwana Res., 25, 729-735, https://doi.org/10.1016/j.gr.2013.09.010, 2013.

Schattner, U. and Weinberger, R.: A mid-Pleistocene deformation transition in the Hula basin, northern Israel: Implications for the tectonic evolution of the Dead Sea Fault, Geochem. Geophy. Geosy., 9, Q07009, https://doi.org/10.1029/2007GC001937, 2008.

Schattner, U., Ben-Avraham, Z., Reshef, M., Bar-Am, G., and Lazar, M.: Oligocene-Miocene formation of the Haifa basin: Qishon-Sirhan rifting coeval with the Red Sea-Suez rift system, Tectonophysics, 419, 1-12, 2006a.

Schattner, U., Ben-Avraham, Z., Reshef, M., Bar-Am, G., Lazar, M., and Hüebscher, C.: Tectonic isolation of the Levant basin offshore Galilee-Lebanon- effects of the Dead Sea fault plate boundary on the Levant continental margin, eastern Mediterranean, J. Struct. Geol., 28, 2049-2066, 2006 b.
Schulman, N.: The geology of the Central Jordan valley, PhD Thesis, the Hebrew University of Jerusalem, Jerusalem, Israel, 103 pp., 1962 (in Hebrew with English summary).

Schulman, N. and Rosenthal, E.: Neogene and Quaternary of the Marma Feiyad area south of Bet She'an, Israel J. Earth Sci., 17, 54-62, 1968.

Segev, A.: The principal Phanerozoic tectono-magmatic periods in the Levant and their stratigraphic record, Israel Geological Survey Current Research, 12, 115-124, 2000.

Segev, A. and Eshet, Y: Significance of $\mathrm{Rb} / \mathrm{Sr}$ ages of Early Permian volcanics and late Precambrian schist, Helez Deep 1A borehole, central Israel, Africa Geosci. Rev., 10, 333-345, 2003.

Segev, A. and Rybakov, M.: History of faulting and magmatism in the Galilee (Israel) and across the Levant continental margin inferred from potential field data, J. Geodyn., 51, 264-284, https://doi.org/10.1016/j.jog.2010.10.001, 2011.

Segev, A., Rybakov, M., Lyakhovsky, V., Hofstteter, A., Tibor, G., Goldshmidt, V., and Ben-Avraham, Z.: The structure, isostasy and gravity field of the Levant continental margin and the southeast Mediterranean area, Tectonophysics, 425, 137-157, 2006.

Segev, A., Schattner, U., and Lyakhovsky, V.: Middle-Late Eocene structure of the southern Levant continental margin- Tectonic motion versus global sea-level change, Tectonophysics, 499, 165-177, https://doi.org/10.1016/j.tecto.2011.01.006, 2011.

Segev, A., Lyakhovsky, V., and Weinberger, R.: Continental transform-rift interaction adjacent to a continental margin: The Levant case study, Earth-Sci. Rev., 139, 83-103, 2014.

Segev, A., Avni, Y., Shahar, J., and Wald, R.: Late Oligocene and Miocene different seaways to the Red Sea-Gulf of Suez rift and the Gulf of Aqaba-Dead Sea basins, Earth-Sci. Rev., 171, 196219, https://doi.org/10.1016/j.earscirev.2017.05.004, 2017.

Segev, A., Sass, E., and Schattner, U.: Age and structure of the Levant basin, Eastern Mediterranean, Earth-Sci. Rev., 182, 233-250, https://doi.org/10.1016/j.earscirev.2018.05.011, 2018.

Şengör, A. M. C.: Sedimentation and tectonics of fossil rifts, Tectonics of sedimentary basins, 579, 53-118, 1995.

Shaliv, G.: Stages in the tectonic and volcanic history of the Neogene basin in the Lower Galilee and the valleys, Israel Geological Survey Report GSI/11/91, 101 pp., 1991.

Shaliv, G.: Analysis groundwater flow regime in the Bet-Shean Valley and at the Mount Gilboa margins as a basis of conceptual model construction, Ministry of Infrastructures Report 068/01, 2003 (in Hebrew).

Shaliv, G.: Preliminary hydrogeological feasibility study for water production from the Gilboa Tunnel, Water Authority report, 2005 (in Hebrew).

Shaliv, G., Mimran, Y., and Hatzor, Y.: The sedimentary and structural history in the Bet She'an area and its regional implications, Israel J. Earth Sci., 40, 161-179, 1991.

Shamir, G.: Earthquake epicentre distribution and mechanisms in northern Israel, Israel Geological Survey Report GSI/16/2007, Jerusalem, Israel, 40 pp., 2007 (in Hebrew with English abstract).

Sharma, R. S. (Ed.): Cratons and fold belts of India, Lect. Notes Earth Sci., 127, 304 pp., Springer-Verlag, Berlin Heidelberg, Germany, https://doi.org/10.1007/978-3-642-01459-8, 2009.

Smit, J., Brun, J. P., Cloetingh, S., and Ben-avraham, Z.: The riftlike structure and asymmetry of the Dead Sea Fault, Earth and Planet. Sc. Lett., 290, 74-82, 2010. 
Sneh, A.: Geological map, $1: 50000$, Shefar'am Sheet, 3-II, Israel Geological Survey, Jerusalem, 2008.

Sneh, A. and Buchbinder, B.: Miocene to Pleistocene surfaces and their associated sediments in the Shfela region, Israel, Geological Survey of Israel Current Research, 1983-1984, 60-64, 1984.

Sneh, A., Bartov, Y., Weissbrod, T., and Rosensaft, M.: Geological Map of Israel, $1: 200000$, Israel Geological Survey (4 sheets), 1998.

Sneh, A., Bartov, Y., and Weissbrod, T.: Stratigraphic chart of exposed rock units in Israel, Geological Survey of Israel Current Research, 12, 257-262, 2000a.

Sneh, A., Bartov, Y., Weissbrod, T., Rosensaft, M., and Hall, J. K.: Geological Shaded-Relief Map of Israel and Environs: Israel Geological Survey, scale 1 : 500000 , Jerusalem, $2000 \mathrm{~b}$.

Stampfli, G. M. and Hochard, C.: Plate tectonics of the Alpine realm, Geol. Soc. London Spec. Pub., 327, 89-111, 2009.

Stein, M. and Goldstein, S. L.: From plume head to continental lithosphere, Nature, 382, 773-778, 1996.

Steinberg, J., Gvirtzman, Z., Folkman, Y., and Garfunkel, Z.: Origin and nature of the rapid late Tertiary filling of the Levant Basin, Geology, 39, 355-358, 2011.

Steckler, M. S. and ten Brink, U. S.: Lithospheric strength variations as a control on new plate boundaries: examples from the northern Red Sea region, Earth Planet. Sc. Lett., 79, 120-132, 1986.

Stein, M. and Goldstein, S. L.: From plume head to continental lithosphere in the Arabian-Nubian Shield, Nature, 382, 773-778, https://doi.org/10.1038/382773a0, 1996.

Stern, R. J.: The Najd Fault System, Saudi Arabia and Egypt: A Late Precambrian rift-related transform system?, Tectonics, 4, 497$511,1985$.

Stern, R. J.: Arc Assembly and continental collision in the Neoproterozoic East African Orogen: Implications for the assembly of Gondwanaland, Annu. Rev. Earth Pl. Sc., 22, 319-351, 1994.

Stern, R. J. and Johnson, P.: Continental lithosphere of the Arabian plate; a geologic, petrologic, and geophysical synthesis, EarthSci. Rev., 101, 29-67, 2010.

Van Wijk, J. W. and Blackman, D. K.: Dynamics of continental rift propagation: the end-member modes, Earth Planet. Sc. Lett., 229, 247-258, 2005.

Wald, R.: Interpretation of the Lower (southern) Galilee tectonic evolution from Oligocene truncation to Miocene-Pliocene deformation using geological and geophysical subsurface data. Ph.D. Thesis, University of Haifa, Haifa, Israel, 196 pp., 2016 (in Hebrew with English abstract).

Wald, R., Schattner, U., Segev, A., and Ben Avraham, Z.: Initiation of Arabian Plate Exposure during the Oligocene, evidence from the Galilee, Israel, AAPG International Conference Abstract, Istanbul, 2014.

Wald, R., Schattner, U., Segev, A., and Ben Avraham, Z.: Tethys Ocean withdrawal and continental peneplanation - an example from the Galilee, northwestern Arabia, J. Geodynam., under review, 2019.
Walley, C. D.: Some outstanding issues in the geology of Lebanon and their importance in the tectonic evolution of the Levantine region, Tectonophysics, 298, 37-62, 1998.

Weiler, Y.: Geology of Nazareth Hills and Mount Tabor (southern Galilee, Israel), Israel J. Earth Sci., 17, 63-82, 1968.

Weinberger, R., Schattner, U., Medvedev, B., Frieslander, U., Sneh, A., Harlavan, Y., and Gross, M. R.: Convergent strike-slip across the Dead Sea Fault in northern Israel, imaged by highresolution seismic reflection data, Israel J. Earth Sci., 58, 143156, https://doi.org/10.1560/IJES.58.3-4.203, 2010.

Weinstein, Y.: Spatial and temporal geochemical variability in basin-related volcanism, northern Israel, J. Afr. Earth Sci., 30, 865-886, 2000.

White, R. S., Smith, L. K., Roberts, A. W., Christie, P. A. F., and Kusznir, N. J.: Lower-crustal intrusion on the North Atlantic continental margin, Nature, 452, 460-464, https://doi.org/10.1038/nature06687, 2008.

Wishkin, Y.: Geology and geochemistry of the water as a basis for understanding groundwater hydrological regime, MSc Thesis, the Hebrew University, Jerusalem, Israel, 56 pp., 1973 (in Hebrew with English abstract).

Yair, A.: Geomorphological phenomena in Tavor and Yissaskhar watersheds, PhD Thesis, the Hebrew University, Jerusalem, 1968 (in Hebrew with English abstract).

Younes, A. I. and McClay, K. R.: Development of accommodation zones in the Gulf of Suez-Red Sea rift, Egypt, Am. Assoc. Petr. Geol. B., 86, 1003-1026, 2002.

Ziegler, P. A. and Cloetingh, S.: Dynamic processes controlling evolution of rifted basins, Earth-Sci. Rev., 64, 1-50, https://doi.org/10.1016/S0012-8252(03)00041-2, 2004.

Zilberman, E.: Landscape evolution in the central, northern and northwestern Negev during the Neogene and the Quaternary, Israel Geological Survey Report GSI/45/90, 164 pp., 1989 (in Hebrew, English abstract).

Zilberman, E.: Remnants of Miocene landscape in the central and northern Negev and their paleogeographic implications, Israel Geological Survey Bulletin, 83, 54 pp., 1992.

Zilberman, E., Gvirtzman, Z., Nahmias, Y., and Porat, N.: Evidence for Late Pleistocene and Holocene tectonic activity along the Bet Qeshet faults, Israel Geological Survey Report GSI/06/2009, 23 pp., 2009 (in Hebrew).

Zilberman, E. and Calvo, R.: Remnants of Miocene fluvial sediments in the Negev Desert, Israel, and the Jordanian Plateau: Evidence for an extensive subsiding basin in the northwestern margins of the Arabian plate, J. Afr. Earth Sci., 82, 33-53, 2013.

Zilberman, E. and Sandler, A.: Coastlines and morphological levels of the Western Lower Galilee - Key of reconstruction of landscape evolution, as response to uplift processes and stable periods, Israel Geological Society Annual Meeting Field Trips Guide, Acco, 18-33, 2013 (in Hebrew). 